\title{
Urban trading of medicinal plants in San Salvador de Jujuy (Argentina): How does species composition vary between different biocultural supply sites?
}

\author{
Marina Eva Acosta ${ }^{1}$, Daniela Alejandra Lambaré ${ }^{1}$ and Ana H. Ladio ${ }^{2 *}$
}

\begin{abstract}
Studies on the biocultural variation of medicinal plant use in urban contexts are necessary for public health purposes. We asked: What are the main supply sites of medicinal plants in the pluricultural city of San Salvador de Jujuy, and how can we characterize them? What are the most important medicinal plants commercialized in the city? How does species composition vary between commercial suppliers? We also studied the relationship between plants' therapeutic versatility and their commercial importance, the main illnesses treated and the botanical families involved. Ethnobotanical techniques were employed, particularly participant observation and semi-structured and structured interviews with salespersons. Three types of supply site were identified: pharmacies, herbal stores and traditional informal sales stalls (informal vendors). Eighty-two medicinal species, mainly belonging to the Asteraceae family, and two algal species were the most sold. Total species richness differed between supply site types with herb stores selling the highest richness (54 species). The most frequently used species were the most versatile, the most sold native species being more therapeutically versatile than the exotic species. Through a GLM we found that the supply sites most likely to sell native plants were informal vendors. These traditional vendors are fundamental in Jujuy for the supply of unique native species. This has marked consequences for public health, highlighting the essential biocultural role played by this supply point in maintaining the traditional Andean health system. Furthermore, having diverse medicinal plant supply sites may contribute to inhabitants' social-ecological resilience, helping them face changes with autonomy and diversity.
\end{abstract}

Keywords: Urban ethnobotany; Therapeutic versatility; Andean species.

1 Grupo de Etnobiología y Micrografía Aplicada (GEMA), Instituto de Ecorregiones Andinas (INECOA), (CONICET-UNJu), San Salvador de Jujuy, Jujuy, Argentina.

2 Grupo de Etnobiología. INIBIOMA. CONICET-Universidad Nacional del Comahue, Quintral 1250, S.C. de Bariloche, Río Negro, Argentina.

* Corresponding author $\bowtie$. E-mail address: AHL (ahladio@gmail.com) 


\section{SIGNIFICANCE STATEMENT}

Carrying out ethnobotanical studies in cities is a complex task, particularly because of their biocultural variability. In this work, we study the composition and variation of medicinal species sold in the city of S.S. de Jujuy (Argentina), where different types of supply site, with different biocultural particularities, coexist. We found that the less traditional supply sites, such as pharmacies, were more likely to offer exotic plants, while herbal stores and informal vendors offered more native plants. In this context the more traditional sites, the informal vendors, act as the most important points for the circulation and refuge of native or wild medicinal species. This information is useful for the design and implementation of multicultural health policies in cities, favoring the localization and protection of essential resources which promote the good health of inhabitants.

\section{INTRODUCTION}

Urban botanical knowledge is a complex system that varies according to the pluricultural context and internal biocultural variation of cities (Hurrell 2014). In Argentina, as in other countries, the commercialization of medicinal plants in cities is increasing in importance, providing an alternative for primary health care systems (Balick et al. 2000; Bussman et al. 2016; Cuassolo et al. 2010; Luján and Martínez 2019; Molares et al. 2012; Tinitana et al. 2016). However, each city has its own dynamic environment that favors circulation and consumption through formal and informal commerce. Traditions are reproduced, innovations developed, and practices from diverse cultural contexts, based on different philosophical positions, are shared (Balick et al. 2000; Cuassolo et al. 2010; Hilgert et al. 2010; Hurrell 2014; Luján and Martínez 2017; Smith-Hall et al. 2012).

There is a clear need to focus research on medicinal plant use in urban areas, not only to increase understanding of local medical systems but also for public health purposes (Zhou et al. 2019). It would be particularly useful to analyze different commercialization sites, which can be interpreted as reservoirs of plants and herbal traditions (Pirondo et al. 2011). Many studies in urban areas (Arenas et al. 2011; Hurrell et al. 2011a; Pochettino et al. 2012) have found that supply sites contribute greatly to local medicinal plant richness. These studies have also highlighted their function as centers for the diffusion of plant knowledge and herbal products. However, internal urban socio-environmental variation in aspects like their different supply sites has not been considered. In general, studies have focused on specific cultural groups within cities or compiled an inventory of the total plants commercialized (Macía et al. 2005; Hurrell et al. 2011b).

Interestingly, however, in the city of Hurlingham (Argentina), Bach et al. (2014) found that retail sales of native species were higher in herbal stores than in pharmacies because the owners generally gathered the native plants themselves or had close contact with local gatherers. These results suggest possible taxonomic specificity in different types of medicinal plant retail sites, which could orient plant selection by urban dwellers. The idea of having plants from multiple sources is assumed to provide more security of supply in the face of unexpected disturbance (Davoudi et al. 2012). Exploration of this subject will therefore aid our understanding of the resilience processes of urban medical systems. As pointed out by Ceuterick et al. (2011), medicinal plant diversity is a key element in promoting resilience in inhabitants of multicultural environments, bringing solutions in terms of the reorganization and renewal of home remedies.

Many of the medicinal species found in cities are associated with the treatment of ailments that are "modern" or typical of a consumer society, such as obesity, stress and depression (Arenas 2007; Cuassolo 2009; Hurrell et al. 2011b; OIM 2015; Porqueddu 2017). Advertisements for these species and their products promote new aspects of their attributes, highlighting their good properties and the benefits they confer (Ceuterick et al. 2011; Hurrell 2014; Hurrell et al. 2015). Moreover, the use of herbal medicine in certain traditional and/or migrant groups living in cities is strongly linked to primary health care; that is, the treatment of ailments that can be dealt with in the home, using simple home remedies such as herb infusions, herbal baths, poultices and inhalations, mainly for digestive and respiratory disorders (Pochettino et al. 2008; Ladio and Acosta 2019).

One of the prominent features of herbalism in urban centers appears to be the use of plants that are mainly Eurasian in origin, and particularly botanical families like Asteraceae and Lamiaceae, of which the aerial parts, such as leaves, are the most frequently used (Hernández and Arambarri 2011; Ladio and Acosta 2019; Leitão et al. 2014; Macía et al. 2005; Pochettino et al. 2008). Non-native plants introduced at different historical moments into South America, such as during the Spanish Colonization, have greatly increased the plant richness of local medical systems. At present, these exotic medicinal plants are mainly found in urban contexts (Abreu et al. 2015; Alencar et al. 2014; Hart et al. 2017; Hilgert et al. 2010; Medeiros et al. 2017; Nascimento et al. 2018; Pirondo et al. 2018; Tareau et al. 2017).

The interchange of plants between pharmacopeias 
has been interpreted by Moerman et al. (1999) as a non-random process, a consequence of the global pattern of human knowledge. This means that in medicinal plant systems some botanical families are underrepresented and others overrepresented. Since medicinal plants of a given taxonomic family are likely to share features, the possibility of species having similar medicinal uses increases within the same botanical family. This results in most societies using herbal remedies belonging to two botanical families, Asteraceae and Lamiaceae, which contain key bioactive compounds and are extensively distributed worldwide (Bennett and Husby 2008; Ladio and Acosta 2019). Saslis-Lagoudakis et al. (2012), who used a phylogenetic approach to study the medicinal flora of Nepal, New Zealand and South Africa, found that the crosscultural agreement in plant medicinal use provides distinctive evidence about the importance of plant selection in local medical systems, which currently includes both native and exotic species.

Due to human patterns of exchange and migration, exotic species have been introduced into many places worldwide. These species are incorporated into the new local medical system in different ways, showing adaptability (Santoro et al. 2018). Exotic plant use could be associated with replacement or substitution phenomena due to the abandonment of use of certain plants, mainly native species, which for diverse reasons (e.g., local extinction of a species due to overexploitation or the appearance of new illnesses) can be used no longer (Medeiros 2013). However, exotic plants can also be part of a process of diversification, extending the repertoire of medicinal species and offering greater flexibility to local medical systems and/or filling gaps left by native species (Alencar et al. 2010; Hart et al. 2017; Medeiros et al. 2017). These processes of bringing exotic medicinal plants into local systems may have multiple bases that depend on specific cultural contexts (Medeiros 2013).

To explain the inclusion of exotic plants in pharmacopoeias, many authors have suggested that introduced species are more versatile, and therefore have a higher probability of being used than native species (Alencar et al. 2010; Hart et al. 2017). This attribute is referred to as therapeutic versatility: plants with many different simultaneous roles cover a wide range of diseases and symptoms (Alencar et al. 2010; Hart et al. 2017). However, results from a study conducted by Rossi-Santos et al. (2018) in Brazil apparently contradicted this, since native and exotic species had similar versatility.

Richeri et al. (2013) found in a Patagonian rural community that therapeutic versatility is an important attribute of species with high cultural consensus (such as the native Acantholippia seriphioides and Valeriana spp. and the exotic Mentha spp. and
Artemisia absinthium. This was interpreted by the authors as part of the processes of resilience and cultural adaptation that favor self-sufficiency in their medical systems.

This aspect has been little studied in cities. For example, Cuassolo (2009) found that the medicinal plants most frequently sold in the city of Bariloche (Patagonia, Argentina) had the highest therapeutic versatility, such as Matricaria chamomilla (camomile) and Malva sp. (mallow), both exotic species. We interpret that plants become popular when they are multipurpose and effective, aspects that could be favorable in urban life with little access to plants. In addition, it is important to clarify that in these studies therapeutic versatility and biogeographical origin were not analyzed specifically, but the particular importance of certain species (native or exotic) stood out culturally due to their key role in combating local ailments.

Andean medicine is prevalent in the province of Jujuy, situated in northwest Argentina, where healing methods and medicinal plant remedies are influenced by strong religious and symbolic connotations (Vandebroek et al. 2004). The multicultural city of San Salvador de Jujuy is a particularly good scenario for the study of the continuity of Andean keystone species and the blending with new resources. Characterization of the commercialization of medicinal plants used to alleviate and cure health problems could highlight the importance of plant resources in the folk medicine and culture of urban dwellers.

In this context our questions are the following: What are the main supply sites of medicinal plants in the pluricultural city of San Salvador de Jujuy, and how can we characterize them? What are the most important medicinal plants commercialized in the city? How does species composition vary between commercial suppliers? Is the proportion of exotic and native species similar for all suppliers? What differences exist between supply sites in terms of botanical families, life forms and the most common medicinal use categories treated? What are the levels of similarity of the plants sold at each site? These descriptive questions on the medical system components were enriched by the following main hypotheses and predictions (Table 1).

\section{MATERIAL AND METHODS}

\section{Study site}

This study was carried out in the city of San Salvador de Jujuy (S. S. de Jujuy), the capital of Jujuy province (Figure 1), which is located in the extreme

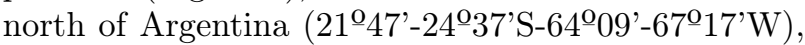
and covers an area of $53,219 \mathrm{~km}^{2}$. Jujuy is one of the 
Table 1. Summary of the principal hypotheses and predictions.

\begin{tabular}{|c|c|c|}
\hline Theoretical Background & Hypothesis & Prediction \\
\hline $\begin{array}{l}\text { 1. Therapeutic versatility of } \\
\text { medicinal plants is higher for ex- } \\
\text { otic than native species (Hart et } \\
\text { al. 2017, Alencar et al. 2010). }\end{array}$ & $\begin{array}{l}\text { Selection of species is associated } \\
\text { with therapeutic versatility and } \\
\text { plant origin. }\end{array}$ & $\begin{array}{l}\text { The most frequently sold plants } \\
\text { in the city are the most versatile } \\
\text { (a). Bestselling exotic species } \\
\text { are more versatile than native } \\
\text { species (b). }\end{array}$ \\
\hline $\begin{array}{l}\text { 2. Global pattern of cosmopoli- } \\
\text { tan medicinal plants of Moerman } \\
(1999) \text {. }\end{array}$ & $\begin{array}{l}\text { Due to global patterns, exotic } \\
\text { species are prevalent: mainly } \\
\text { from Asteraceae and Lamiaceae } \\
\text { families (a) and are mainly herbs } \\
\text { (b) in this multicultural context. }\end{array}$ & $\begin{array}{l}\text { The highest species richness will } \\
\text { be for plants of exotic origin, } \\
\text { mainly the Asteraceae and Lami- } \\
\text { aceae families, and will princi- } \\
\text { pally be herbaceous in life form. }\end{array}$ \\
\hline $\begin{array}{l}3 . \quad \text { Plants used for digestive } \\
\text { and diuretic categories are preva- } \\
\text { lent in urban contexts (Cuassolo } \\
2009 \text { ). }\end{array}$ & $\begin{array}{l}\text { Medicinal plants used for diges- } \\
\text { tive and diuretic purposes are } \\
\text { used in high proportions. }\end{array}$ & $\begin{array}{l}\text { The highest percentage of plants } \\
\text { sold will be used for digestive and } \\
\text { diuretic purposes. }\end{array}$ \\
\hline $\begin{array}{l}\text { 4. Medicinal native plants are } \\
\text { more common in traditional lo- } \\
\text { cal retail sites (informal vendors) } \\
\text { than pharmacies, since they are } \\
\text { more associated with local gath- } \\
\text { erers (Bach et al. 2014). }\end{array}$ & $\begin{array}{l}\text { Biogeographical plant origin } \\
\text { varies between supply sites. }\end{array}$ & $\begin{array}{l}\text { a- Less traditional supply sites } \\
\text { (pharmacies) will sell more ex- } \\
\text { otic species than more tradi- } \\
\text { tional ones (informal vendors } \\
\text { and herbal stores). }\end{array}$ \\
\hline
\end{tabular}

provinces with the highest richness of vascular plant species in the country, with 170 families, 972 genera and 2831 species. The Asteraceae family is the most represented, with 488 species (Zuloaga et al. 1999). The city of S. S. de Jujuy is situated within the phytogeographical zone of Montane Cloud Forests, which extends from 500 to $1600 \mathrm{~m}$ asl. (Cabrera 1976). The topography is mountainous, with the rivers Grande and Xibi-Xibi running through it. The city lies between 1200 and $1300 \mathrm{~m}$ asl. and has a subtropical highland climate, with dry winters and summers which are hot and rainy. The average annual temperature is $16.4^{\circ} \mathrm{C}$ (Cabrera 1976).

The population of S. S. de Jujuy is 257,970 (INDEC 2010). The economic activity of inhabitants is based mainly on employment in the public sector and commercial activity; state social benefits also constitute an important part of family income. A large number of migrants reside in this city, the majority of whom are Bolivian (8502 inhabitants) (INDEC 2010).

\section{Ethnobotanical survey}

A total of 31 supply sites were surveyed in the city of S. S. de Jujuy. These sales points were first approached randomly in the street and subsequent interviews were performed gradually using the snowball technique, leading to non-probabilistic sampling. In addition, we used a list of pharmacies provided by the Departamento de Farmacia de la Provincia de Jujuy. The supply site category was afterwards defined according to local conditions: pharmacies, herbal stores (including health food stores) and informal vendors (including street market stalls and informal points of sale in the area). It should be mentioned that some of the informal sales points are not permanent, so they could be surveyed only when the opportunity arose (Albuquerque et al. 2014). The number of points of sale analyzed represents $30 \%$ of the total number in existence.

Written consent was obtained at each sales point before carrying out the fieldwork, following the Code of Ethics of the International Society of Ethnobiology (ISE 2006). Semi-structured anonymous interviews were conducted in Spanish with each vendor at each site in 18 pharmacies, 4 herbal stores and 9 informal sales points (Additional file 1). The main questions asked during each interview were as follows: What plants were sold most over the last year? What are they used for? Which parts of the plant are used? How are they used? What medicinal use do customers mainly buy medicinal plants for? Do you know any medicinal plants that are native to Jujuy? Do you sell plants from other places (e.g., China, Europe)? Who comes to buy medicinal plants?

Free listing of the 10 main medicinal plants mar- 


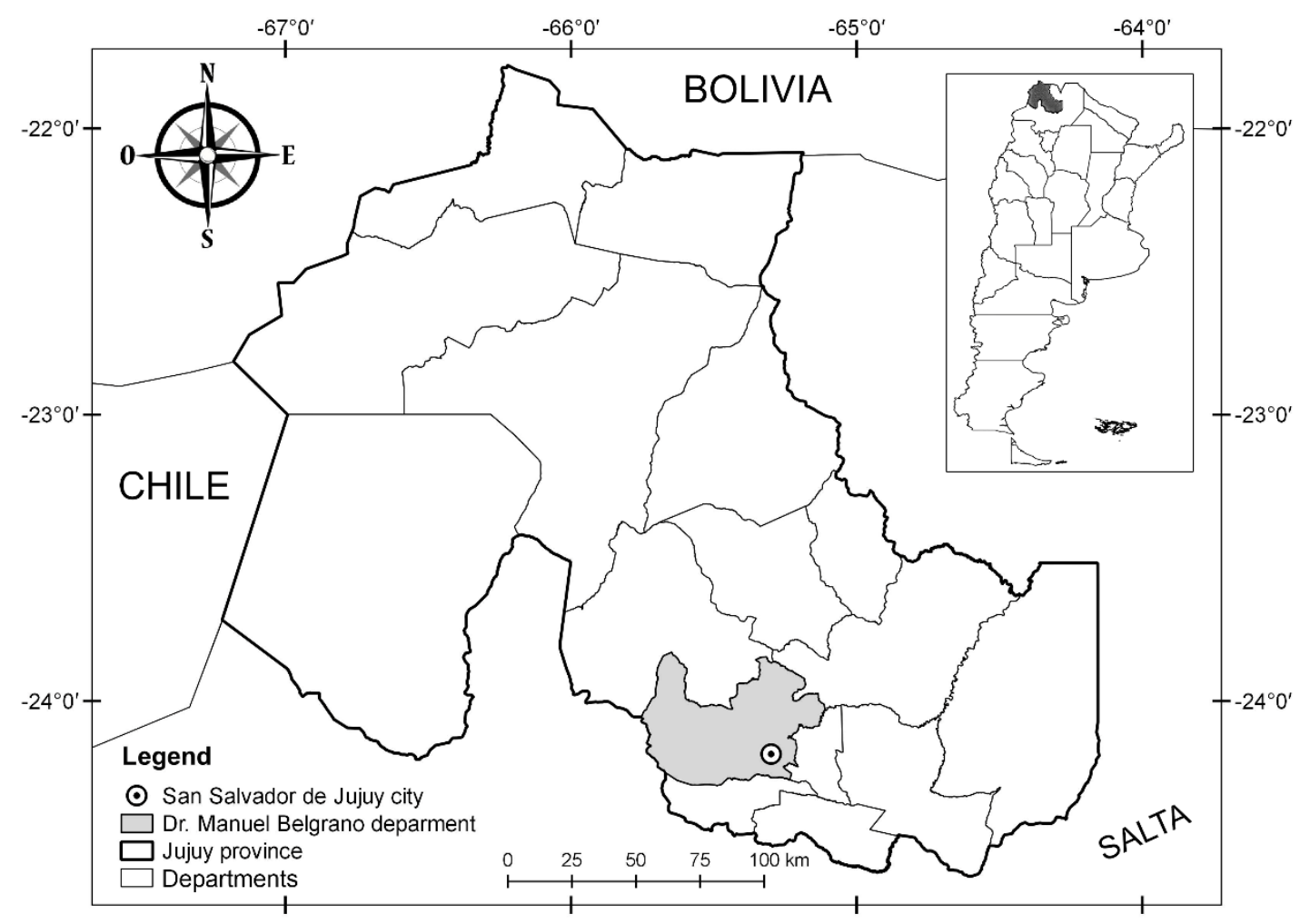

Figure 1. Location of San Salvador de Jujuy in Jujuy province (Argentina).

keted in the city was also carried out, from the perspective of the participant. We focused on the 10 most sold species for two reasons. Firstly, because our sampling design is based on consultation with retailers, we decided to concentrate on the species most known to them through marketing; they were able to cite the different uses assigned to the species with a high degree of knowledge. Thus, the therapeutic versatility cited emerges from a detailed process for all the species involved. Second, due to methodological reasons this simplified the fieldwork at each retail site. Although this decision may limit the findings of the study, we believe it enabled us to provide trustworthy results on the main species that form part of the urban medicinal system.

The general description of plant commercialization and the supply sites are also the result of participant observation, using an emerging qualitative approach that implies inductive data collection and analysis (Creswell 2007).

The most common medicinal use categories treated by the species cited were also documented from an etic perspective; that is, through reinterpretation and perception on the part of the researcher but based on the emic categories expressed by informants in their own language, which reflects the ways locals perceive these resources (Martin
2001). The re-categorization of medicinal use categories follows Molares and Ladio (2009), using corporal system categories or common diseases.

Plant material acquired at the different sales points was placed in the Collection of GEMA (Grupo de Etnobiología y Micrografía Aplicada), Vouchers \#M-GEMA 01-84). Botanical samples from fresh plant material were pressed and dried using conventional techniques. Most samples, however, consisted of dried, often sterile and fragmented material. All samples were identified using standard botanical literature and voucher specimens of the reference collections of GEMA. Taxonomic identification of the species was carried out using external morphological plant characters with the help of standard botanical bibliography (Boelcke 1992; Cabrera 1978, 1983, 1993; Cañigueral et al. 1998; Gurni and Wagner 2003; Hauman 1984; Hurrell et al. 2011a; Jackson and Snowdob 1990; Vignale and Gurni 2009; Vignale 2002; Zuloaga and Morrone 1999; Zuloaga et al. 2008).

\section{Data analysis}

For each of the three different types of supply site we determined species composition and richness (the total number of species sold at each one) of the species most frequently sold in the city (Cuas- 
solo 2009). The plants were categorized as native to Northeast Argentina, or as exotic if they did not belong to the vegetation of Argentina, according to Cabrera (1976), Boelcke (1992), Hurrell et al. (2011a), Flora del Cono Sur and Flora Argentina (Zuloaga et al. 2008). Scientific names were updated using the databases www.floraargentina.edu.ar and http: //www . plant sof theworldonline .org.

Total species richness (S) was calculated for all the supply sites, and total richness according to biogeographical origin (native or exotic). Frequency of use was also obtained: $\mathrm{FU}=$ the frequency of citation of a species in relation to the total number of supply sites $(N=31) \times 100$, in order to establish the consensus of each species sold (Molares and Ladio 2009; Tardío and Pardo-de-Santayana 2008). Frequency of use $(\mathrm{FU})$ of plant families was registered in the same way. Therapeutic versatility was obtained considering the sum of different medicinal use categories cited for a given species by the total number of collaborators (Richeri et al. 2013). In general, versatility is not considered separately from consensus of use or popularity (most authors use a combined formula such as use value (UV), reinforcing the importance of investigating therapeutic versatility individually (Caetano et al. 2020).

The Spearman correlation test $(p<0.05)$ was used to analyze the relationship between the FU of medicinal species and their therapeutic versatility. This was calculated for total species and for native and exotic species separately. The sign of the coefficient obtained indicates the direction of the relationship (positive or negative), and the value indicates the strength, with higher absolute values indicating stronger relationships.

The richness of commercialized native and exotic species was compared using the Binomial test $(<0.05)$. FU was also compared between native and exotic plants (Mann Whitney Test, $p<0.05$ ). In addition, the total richness of native and exotic species were compared pairwise between supply sites (Binomial Test, $p<0.05)$. Pairwise statistical differences between supply site types and FU were also analyzed with Mann Whitney Test $(p<0.05)$. For this comparison a database of 309 entries was drawn up, considering all the citations of the species (vascular plants and algae) sold at the three types of sales point.

We also analyzed whether native or exotic medicinal plants varied in their proportions of specific plant families. The contingency table and binomial approach confer flexibility when analyzing medicinal flora (Bennett and Husby 2008). Our null hypothesis was that our dataset $(N=302$, Table 1$)$, in all the categories analyzed, would be distributed equally. It should be noted that algae were not included in this calculation since they are not vascular plants. When comparing the categories of native/exotic (families), the expected proportion according to our model was 0.69 (because for the complete dataset, exotic plants were present in a proportion of 0.69 , Table 2 ). In this way the value was calculated for the number of exotic species expected (Ee) for each family. This comparison was carried out using the Binomial Test $(p<0.05)$ (Agresti 1996).

Chi-square tests $(p<0.05)$ were used to analyze whether plant families, life forms and medicinal categories varied according to supply sites.

To determine the relationships between variables we ran two GLM (Generalized linear models) (Balzarini et al. 2011; Carrascal 2015) (Table 2). The first model was composed of the binomial categorical dependent variable "biogeographical origin" (category $1=$ native; category $0=$ exotic) and the categorical independent variable "sale site" (category $1=$ pharmacies; category $2=$ herbal stores; category $3=$ informal vendors). A second GLM was then run, using the binomial categorical dependent variable, "biogeographical origin" (category $1=$ native; category $0=$ exotic) and the categorical independent variable "life form" ( $1=$ herb; $2=$ tree; $3=$ shrub/climbing plant). These models enabled us to identify which level of explicative factors were the most important for each category (native/exotic): in the first case supply site and in the second life form. Both models used had a binomial distribution and a logit link function, which were significant (Omnibus test, Chi-square test, $p<0.05$ ).

The similarity of commercialized species between supply site types was analyzed using the Jaccard Index (JI) (Real and Vargas 1996), based on the presence or absence of species in each place. Relating the number of species in common to the total number, this is expressed as $J I=\frac{C}{(A+B+C)} \cdot 100$, where $\mathrm{C}$ is the number of species in common, $\mathrm{A}$ is the sum of the species unique to site $\mathrm{A}$ (absent in $\mathrm{B}$ ), and $\mathrm{B}$ is the sum of species cited solely for site B. Statistical tests were carried out using the IBM SPSS statistics program, versions 22 and 25 . 
Table 2. Summary of the variables for construction of the Generalized Linear Models. Total frequency represents the total proportion of species cited for each category. The sites and the life form present total frequencies and percentages $(N=302)$.

\begin{tabular}{llcc}
\hline \hline Variables & Categories & Frequency & Percentage \\
\hline \hline Dependent variable & & & \\
Origin & Exotic & 209 & 69.9 \\
\multirow{2}{*}{ Independent variables } & & 93 & 30.1 \\
& Native & & \\
Supply sites & Herbal store & 64 & 52.4 \\
& Informal vendors & 79 & 22 \\
& Herbs & 159 & 25.6 \\
Life form & Trees & 65 & 51.7 \\
& Shrubs/creepers & 81 & 21.5 \\
\hline \hline
\end{tabular}

\section{RESULTS AND DISCUSSION}

\section{Types of medicinal plant supply site}

Throughout this study three types of supply site with very different qualitative biocultural characteristics were identified for commercialization of medicinal plants in the city, (Figure 2, Table 3, Additional files1). In the pharmacies all the herbal medicines were either located in a small sector of the stores or were not on display for clients. According to the salespeople, the herbal medicines came mainly from Cordoba, Misiones and Buenos Aires provinces, where fractionation and processing of the plants takes place. These products are sent to a distributor in the city of Salta, from where they are sent to pharmacies in the city of Jujuy. Interviewees in only three pharmacies reported fractionating the material for sale themselves. All the products were presented in plastic bags, with labels whose information varied (Figure 2a). In these stores the plants sold were mainly of exotic origin, such as chamomile (Matricaria chamomilla L.), valerian (Valeriana officinalis L.), and small-leaved linden (Tilia cordata Mill.). 

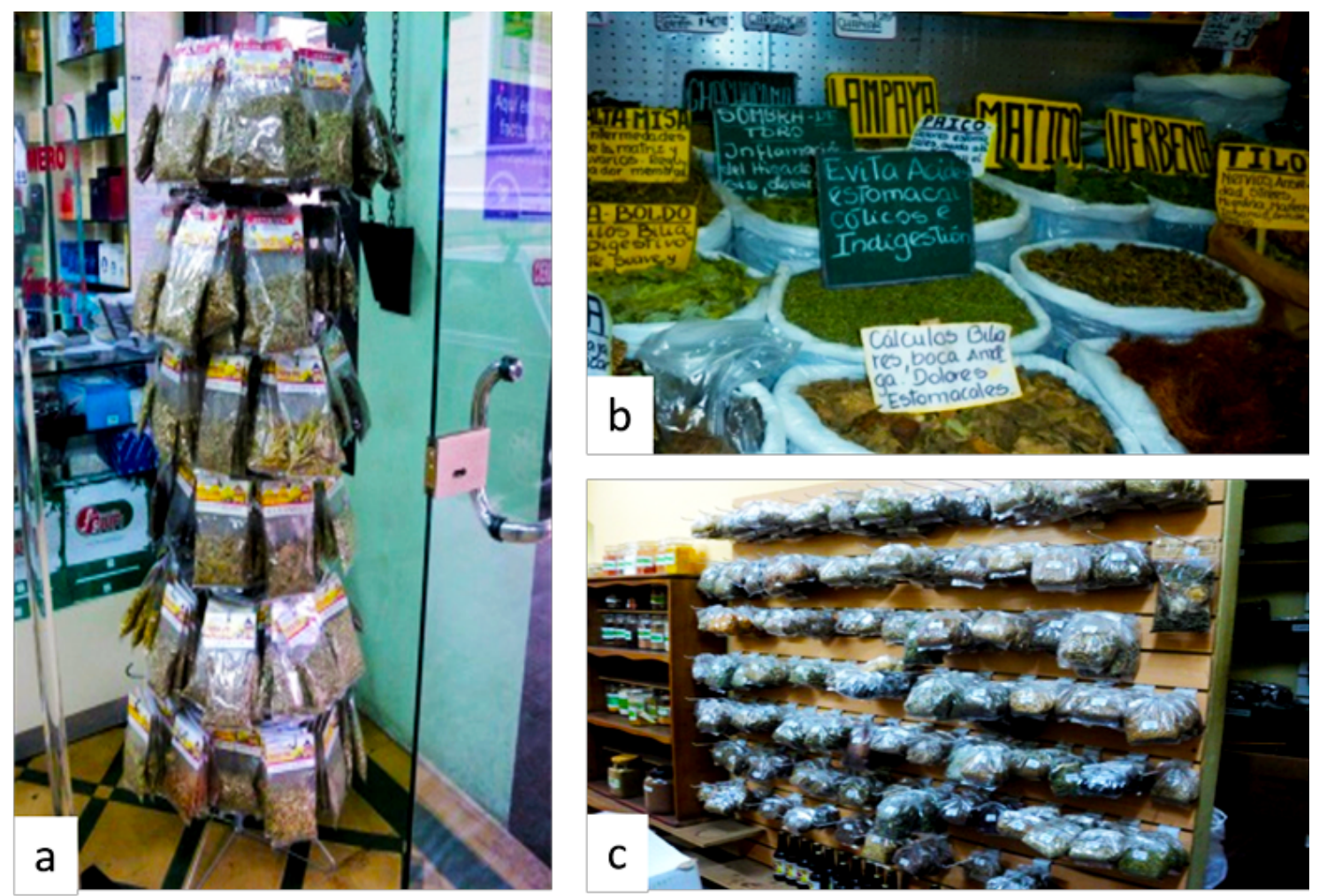

Figure 2. Presentation of medicinal products available for sale at different supply sites: a: Pharmacies; b: Informal vendors; c: Herbal Stores. 
Table 3. Comparison of medicinal plant characteristics between supply sites. N: native; E: exotic; he: herbs; sh: shrub; tr: tree; cr: creeper; al: algae; GI: gastrointestinal; GU: genitourinary; C: circulatory system; AA: analgesic-anti-inflammatory; NS: nervous system. Total richness (R), origin, life form and medicinal use categories are expressed in total number of species.

\begin{tabular}{|c|c|c|c|c|c|c|c|c|c|c|c|c|c|c|c|c|c|c|}
\hline \multirow{2}{*}{$\begin{array}{l}\text { Supply } \\
\text { sites }\end{array}$} & \multirow{2}{*}{$\begin{array}{l}\text { Numbers } \\
\text { of sites }\end{array}$} & \multirow[t]{2}{*}{$\mathbf{R}$} & \multirow{2}{*}{$\begin{array}{l}\mathrm{Nr} \text {. } \\
\text { families }\end{array}$} & \multicolumn{3}{|c|}{ Origin } & \multicolumn{4}{|c|}{ Life form } & \multicolumn{5}{|c|}{$\begin{array}{l}\text { Most frequent } \\
\text { medicinal use categories }\end{array}$} & \multirow[t]{2}{*}{ Vendor } & \multirow{2}{*}{$\begin{array}{l}\text { Plant } \\
\text { suppliers }\end{array}$} & \multirow{2}{*}{$\begin{array}{l}\text { State } \\
\text { of material }\end{array}$} \\
\hline & & & & $\mathbf{N}$ & $\mathbf{E}$ & he & sh & $\operatorname{tr}$ & $\mathrm{cr}$ & al & GI & GU & $\mathrm{C}$ & AA & NS & & & \\
\hline Pharmacies & 18 & 36 & 25 & 7 & 29 & 18 & 6 & 8 & 2 & 1 & 22 & 10 & 7 & 7 & 5 & $\begin{array}{l}\text { Pharmacists, } \\
\text { mainly men }\end{array}$ & $\begin{array}{l}\text { Distributors, } \\
\text { Laborato- } \\
\text { ries. }\end{array}$ & Dry \\
\hline Herbal Stores & 4 & 54 & 34 & 17 & 37 & 32 & 11 & 8 & 4 & 2 & 31 & 16 & 13 & 8 & 9 & $\begin{array}{l}\text { Merchants } \\
\text { and nu- } \\
\text { tritionists, } \\
\text { women }\end{array}$ & $\begin{array}{l}\text { Pharmacies, } \\
\text { laboratories } \\
\text { and local } \\
\text { collectors }\end{array}$ & Dry \\
\hline Informal vendors & 9 & 42 & 23 & 28 & 14 & 20 & 13 & 5 & 3 & 0 & 25 & 6 & 11 & 8 & 6 & $\begin{array}{l}\text { Vendors, } \\
\text { "yuyeras", } \\
\text { women }\end{array}$ & $\begin{array}{l}\text { Local col- } \\
\text { lectors, } \\
\text { cultivation, } \\
\text { from other } \\
\text { countries }\end{array}$ & Dry, Fresh \\
\hline
\end{tabular}


In the herbal stores (which include health food stores) the salespeople or professional nutritionists generally carried out fractionation of the medicinal plants personally. The medicinal species to be sold by weight were presented in dried form, either in glass jars or plastic bags. The labelling of each product stated the common name, price, and in some cases, uses. In addition, food such as dried fruit, honey, and cereals were sold, as well as incense products, perfumed candles and essential oils (Figure 2C). These sales were complemented with products from commercial laboratories. The exotic species found here were chamomile (Matricaria chamomilla L.), valerian (Valeriana officinalis L.), and small-leaved linden (Tilia cordata Mill.); native Argentine plants were also sold, such as southern giant horsetail (Equisetum giganteum L.) and lemon verbena (Aloysia citriodora Palau).

The informal vendors were found either inside or in the area around regional markets. These sales areas, considered more traditional within the city, are representative of Andean culture in terms of sale and exchange points for local inhabitants. They form part of a circuit of internal and family commerce for locals, similar to those found in other countries like Bolivia and Peru (Huamantupa et al. 2011; Macía et al. 2005; Vidaurre 2006). The vendors offered their products by weight, whether fresh or dried (Figure 2b). A great variety of medicinal plants from the Andean region were found here, such as pupusa (Xenophyllum poposum (Phil.) V.A.Funk), espina amarilla (Azorella ulicina (Gillies \& Hook.) G.M. Plunkett \& A.N. Nicolas), lampaya (Lampayo castellani Moldenke), chachacoma (Senecio nutans Sch.Bip.) and yareta (Azorella compacta Phill.). These sales were complemented with packaged products from Bolivia and Peru. Some plants were brought from the vendors' own homes (e.g., chamomile [Matricaria chamomilla L.] cultivated in their gardens), collected in the area around the city (e.g., borage [Borago officinalis L.], collected from the river) or obtained from "people from the countryside". Depending on the time of year or festival to be celebrated in Jujuy (such as the Carnival, Pachamama day [Mother Earth day]) plants with specific uses can be found, generally presented in bunches (either fresh or dried species, whole or cut up, tied in bunches with a ribbon or string). Some sales points sold only medicinal species and plants used for smoking or perfuming, and tended to include the sale of yista (preparations of the ash of different plants with salt, used traditionally for cooking). The vendors situated in the streets close to the markets sold ornamental plants, toiletries and household accessories as well as medicinal plants.

According to the 31 vendors, the main users of these medicinal plants were urban dwellers $(51 \%)$, followed by rural inhabitants $(37 \%)$ and tourists $(5 \%)$. The remaining $7 \%$ were not assigned to any category by the participants. Most of the buyers were over 45 years of age $(53 \%)$. The vendors commented that most of their clients asked for medicinal use categories $(60 \%)$, while the remainder asked for specific plants $(40 \%)$. In addition, all interviewees said that when buying the plants their customers requested instructions for their use: "What is it used for?" "How much do I take?" "How often do I take it each day?". This may indicate that users' choice of species may largely depend on recommendations from the vendors, who share new knowledge and practices that complement the local knowledge of each household.

\section{The most frequently commercialized medicinal plants and their therapeuti- cal versatility}

In the 31 sale sites we estimated a total of 82 plant species as being the most frequently sold, as well as two algal species (Additional file 1). In accordance with our first hypothesis (a), selection of species is associated with therapeutic versatility (Spearman correlation, $r=0.39, p<0.05$, Additional file 1). This relationship between versatility and FU may indicate tendencies the possible adaptive character of this selection of species, given that with a pharmacopeia of few species users can treat a large number of different ailments (Richeri et al. 2012). However, it is important to note the circular relationship that lies behind the link between versatility and popularity. Plant versatility could be increased because people add new uses for plants considered important, or plants become popular because of their increasing versatility (Caetano et al. 2020; Tardío and Pardo de Santayana 2008). In our view, in commercialized settings such as our case, the species marketed are those that have prior recognition of their usefulness, so that their selection would be mediated mainly by their intrinsic multi-purpose characteristics. Urban families can cover a broad spectrum of general care with these plants, simplifying the handling of and access to different species.

The plants with the highest therapeutic versatility are Matricaria chamomilla L. (6 medicinal use categories), followed by Malva parviflora L. (5 categories), and Equisetum giganteum L., Vachellia sp. and Aloysia citriodora Palau (4 categories). These species are highly valued in the region, being used to treat digestive, genitourinary, and respiratory problems, among other uses. This also shows the enormous contribution made by foreign species (e.g., Matricaria chamomilla L., Malva palviflora L.) to the versatility of the urban pharmacopeia. Neverthe- 
less, in disagreement with our first hypothesis (b), we found that the most sold native species had greater therapeutic versatility $(r=0,63, p<0.05)$ than the exotic species $(r=0,24, p<0.05)$. This suggests that the native species, which are highly popular, can respond in multiple ways within the urban herb scenario. These results are in line with those found by Rossi-Santos et al. (2018), indicating that native plants can also be versatile. These findings enable us to see the importance of analyzing particular local contexts, where exotic medicinal plants may play diverse roles.

The most versatile native species found in this study were Equisetum giganteum, Vachellia sp., Aloysia citrodora and Senecio nutans, species which are associated with profound historical selection processes in Andean culture. It is possible that having a versatile, strongly rooted pharmacopeia offers more opportunity for experimentation in this urban context, and therefore also the probability of discovery of further medicinal applications on the part of users.

It should be mentioned that according to the literature consulted, the native species mentioned here are currently not in danger of over exploitation. However, it is important to monitor this situation: an increase in the demand for these species in the future could generate an increase in extraction and put this resource at risk. These results can therefore contribute information that is useful for the design of strategies for conservation of native flora.

\section{Native and exotic species richness in different supply sites}

In accordance with our second hypothesis (a), and considering all the species surveyed, the exotic plants sold presented higher richness $(62 \%, 51$ species $)$ than native species (38\%, 33 species) (Binomial Test, $p<0.05)$. This shows the importance of these foreign species in medicinal plant marketing on a global scale, and their high level of representation in urban herbal medicine (Gama et al. 2018; Stepp 2004; Stepp and Moerman 2001). These global medicinal plants are widely used in many different regions because of their versatility, efficiency and historical dissemination.

However, in contrast to our second hypothesis (a), average $\mathrm{FU}$ values for the native medicinal plants are similar to those of the exotic species (Mann-Whitney Test, $U=777, p=0.541$ ), indicating that in terms of relative cultural importance native plants hold a similar position to exotic ones. Similar results were found in medicinal supply sites of the city of Bariloche (Patagonia, Argentina) (Cuassolo 2009).

In addition, our field work revealed that plant retailers did not seem to distinguish the species according to their biogeographical origin, native or exotic.
This aspect coincides with Hilgert et al. (2010) and shows that this kind of study is useful for analyzing processes related to the biogeography of plant use; this is of great interest from an academic viewpoint, but cannot evaluate the motives, reasons and specific preferences lying behind the people's actions. It should be noted that the similar importance found between native and exotic plants is due to the strong tradition of use of plants that grow in Andean areas, whether wild or cultivated (Acosta 2013; Acosta et al. 2018; Vignale 2001). As proposed by Ceuterick et al. (2011), the Andean health system is characterized by local resilience processes, as the populations preserve their culturally salient species and blend them creatively with exotic plants.

Total species richness differed between the different types of supply site, herbal stores selling the highest total richness (54 species), followed by informal vendors (43 species) and finally, pharmacies (36 species) (Binomial Test, $p<0.05$; Table 3 ). When comparing the three supply sites, it was found that the average richness of the herbal stores was higher than that of the informal vendors (Figure 3, Mann Whitney Test, U: 860; $p<0.05$ ) and pharmacies (Figure 3, Mann Whitney Test, U: 496; $p<0.05$ ), whereas the pharmacies and informal vendors had a similar average richness value (Figure 3, Mann Whitney Test, U: $569 ; p<0.05)$. These results demonstrate that each supply site manages a different range of species, the herbal stores standing out as having the greatest richness of products, as found also by Bach et al. (2014).

\section{Differences between supply sites in terms of botanical families, life forms and most common medicinal use cate- gories}

The total richness of medicinal plants commercialized in the three sites corresponds to 45 botanical families. Plant families with the highest total FU are Asteraceae (17\%), Lamiaceae (8\%), Verbenaceae $(7 \%)$ and Apiaceae $(6 \%)$, in agreement with our second hypothesis (b). The importance of Asteraceae and Lamiaceae has been widely reported (Heinrich 1992; Ladio and Acosta 2019; Leonti et al. 2003; Moerman et al. 1999). On comparing the biogeographical origin of each botanical family, it was found that most families sold were exotic, while from the Equisetaceae, Verbenaceae, Passifloraceae and Amaranthaceae families only native species were sold. However, more exotic species were used than expected in most of the families except Asteraceae, Apiaceae, Equisetaceae, Verbenaceae, Passifloraceae and Amaranthaceae, indicating the over-representation of exotic species (Binomial Test $p>0.05$; Figure 4).

Analysis of the families in relation to supply sites 
showed that the high frequency of Asteraceae in the three supply sites (Figure 5) can be explained, on the one hand, by its abundance in the flora of Jujuy, which is one of the provinces with the highest number of native species in the country (Katinas et al. 2007). In the present study, most of the Asteraceae species recorded are native to Argentina (11 spp, 65\% of total Asteraceae), such as chachacoma (Senecio nutans Sch.Bip.), carqueja (Baccharis articulata (Lam.) Pers.), and pupusa (Xenophylum poposum (Phil.) V.A.Funk). Their high frequency could also be due to the prevalence of other exotic resources belonging to this family (6 spp, $35 \%$ ) (such as chamomile [Matricaria chamomilla] and the common dandelion [Taraxacum officinale]), because of their great physiological adaptability to different soils, climates and topography. Since this enables them to colonize diverse environments, they are distributed widely around the world (Katinas et al. 2007), becoming considered cosmopolitan. People can therefore find these species rapidly, ensuring therapeutic effectiveness at the moment of use (Ladio and Acosta 2019). Similar results were found by Barboza et al. (2009), who noted that Asteraceae is the family with the highest proportion $(17 \%)$ of native medicinal taxa in Argentina. In accordance with Molares et al. (2012) and Kachura and Harris (2021), the Asteraceae family is of great ethnopharmacological significance; this study ratifies the importance of intensifying its investigation with both ethnobotanical and phylogenetic approaches, as proposed by Souza et al. (2018).

A review by Ladio and Acosta (2019) which considered the 30 most cited species in 62 articles published on the topic, has shown that on a global level urban herbal medicine is composed of a corpus of over 500 species, Asteraceae figuring as the most frequently used. Through processes of cultural hybridization, certain social groups continuously construct and contribute to urban pharmacopeias. That is, city pharmacopeias are made up of species and families of cosmopolitan use, as a response to similar health problems, and this is understood to be the result of common patterns of botanical knowledge throughout the world. This knowledge of medicinal species is not a random phenomenon, but rather the result of a selection process based on historical sociocultural processes (Ladio and Acosta 2019).

The Lamiaceae, Verbenaceae and Apiaceae constitute some of the main plant families sold in this city (Figure 5). These families are known for their aromatic structures (Barboza et al. 2009) which contain essential acids with effective bactericidal, virucidal, anti-choleretic, antispasmodic, and lice repellant properties, among others, coinciding with the uses reported in this study. In addition, most of the species belonging to these families are used for gastrointesti-

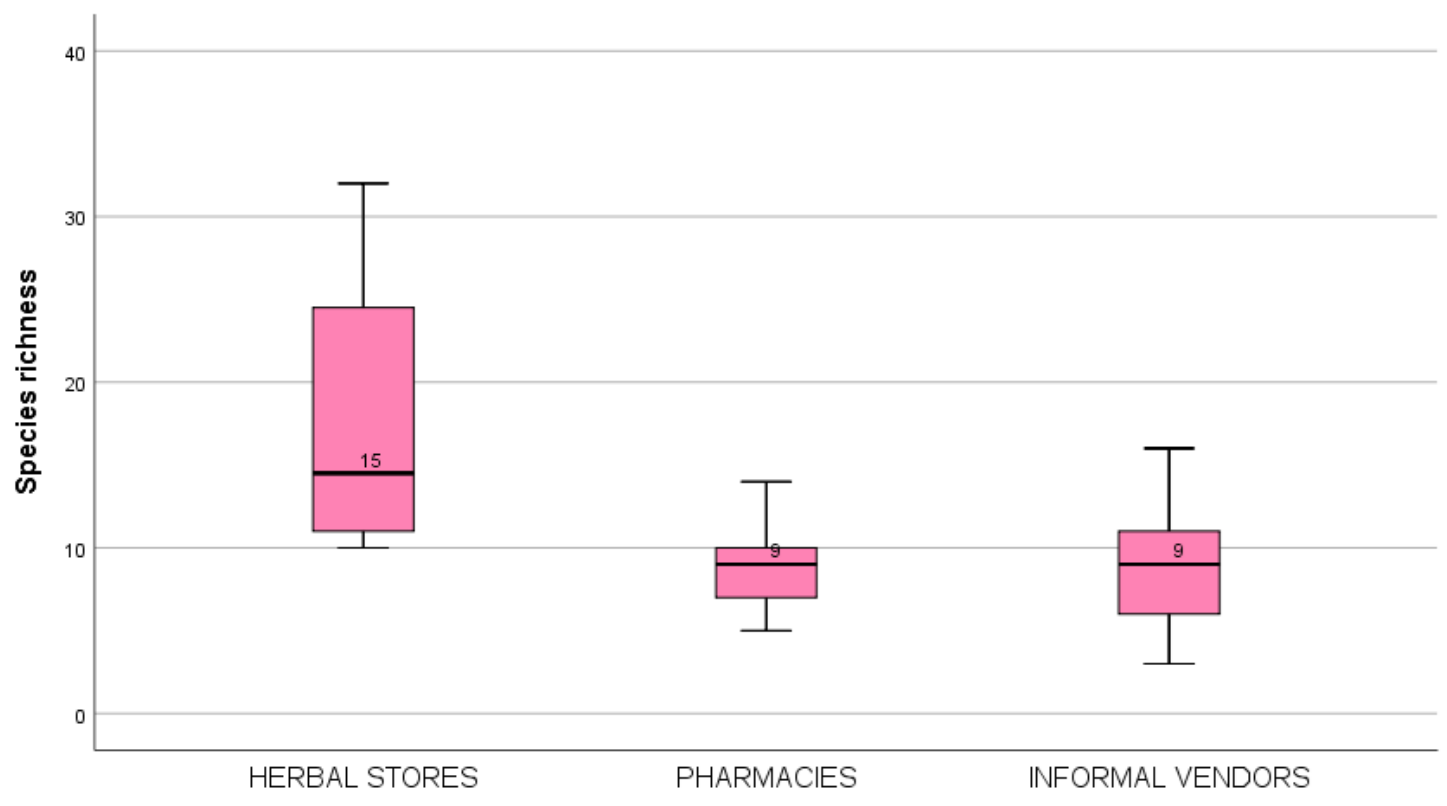

Figure 3. Comparison of richness of medicinal species commercialized in Jujuy. Boxes represent the interquartile range that contains the total data. The black line inside the boxes indicates the average and the bars represent the standard deviation (Herbal Stores: average 15 and SD 9.9; Pharmacies: average 9 and SD 4.1; Informal Vendors: average 9 and SD 2.3). 


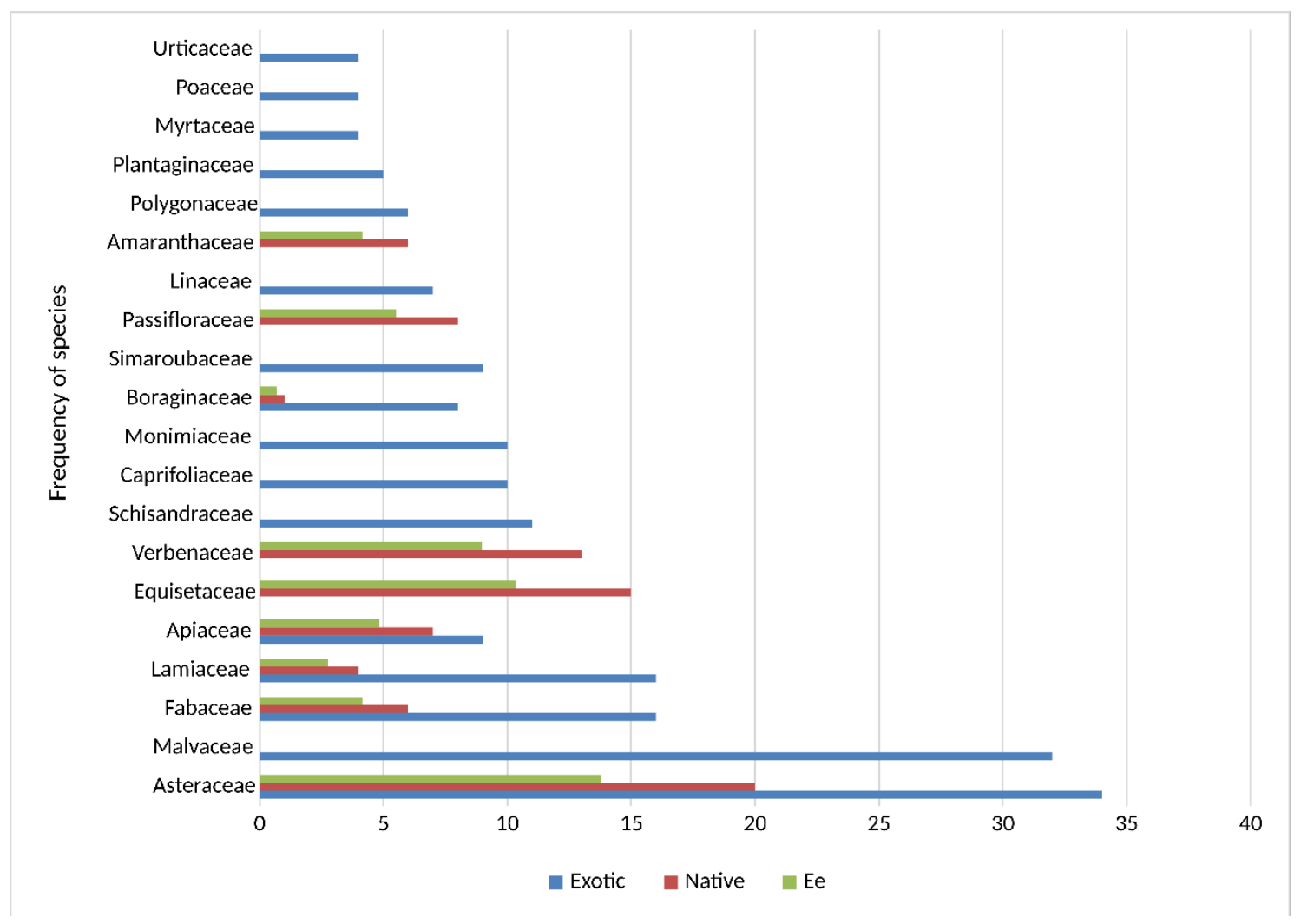

Figure 4. The most representative families according to biogeographical origin: native (red column) or exotic (turquoise column), and Ee, the expected number of exotic medicinal species per family (where $\mathrm{E}=0.69^{*}$ total cites), Families with less than $1 \%$ representativeness are not shown. $N=302$ (total species citations).

nal ailments, in agreement with the literature indicating the versatility of use of these groups (Almeida et al. 2012; Barboza et al. 2009; Richeri 2009).

Differences in botanical families were also found between supply sites (Chi-square tests $(p<0.05)$. In the case of herbal stores and informal vendors, Asteraceae were the most frequently found, while pharmacies sold mostly Malvaceae and Fabaceae (Figure 5). Fabaceae are important due to their wide distribution worldwide and their secondary metabolites, which have medicinal properties (Barboza et al. 2009; Castañeda et al. 2017; Hurrell et al. 2011b; Stepp and Moerman et al. 2001). The variety of chemically active constituents such as tannins, flavonoids, alkaloids, and terpenes often found in members of this family have a high level of biological activity, and the fact that they are used extensively would suggest a global pattern of ethnomedical knowledge (Molares and Ladio 2012). Although records of the Malvaceae family are scarce on a global level (Moerman 1999), in accordance with Guarrera (2005), in our study taxa such as Malva sylvestris L., M. parviflora L. and Tilia cordata Mill were sold and mainly used as digestive and/or analgesic-anti-inflammatory medicines in this urban context.
In addition, each biocultural supply site presented particular characteristics in terms of the plants used and the ways they were sold, and certain botanical families were exclusive to each one (see Table 2). Seven families were exclusive to informal vendors: Cactaceae, Krameriaceae, Piperaceae, Rosaceae, Santalaceae, Amaranthaceae and Brassicaceae; nine families were exclusive to herbal stores: Celastraceae, Cyanophyaceae, Ginkgoaceae, Lauraceae, Papaveraceae, Phyllanthaceae, Rubiaceae and Zingiberaceae, Balanophoraceae; and five families were sold only at pharmacies: Rhamnaceae, Linaceae, Caprifoliaceae, Monimiaceae and Schisandraceae. It was noted that the informal vendors sold plant families which are important in the Andean medicinal flora (Acosta 2013), while the other two types of supply site sold more cosmopolitan medicinal families (Acosta et al. 2013). The exclusivity of certain families at each supply site indicates the importance of continuing the study of their marketing channels (selectors, collectors, intermediaries and mediators between collectors and sales sites), the availability of the plant resource, and harvesting season. This would also provide information on the marketing chain and enable regulation of species extraction, since unlimited harvesting gener- 


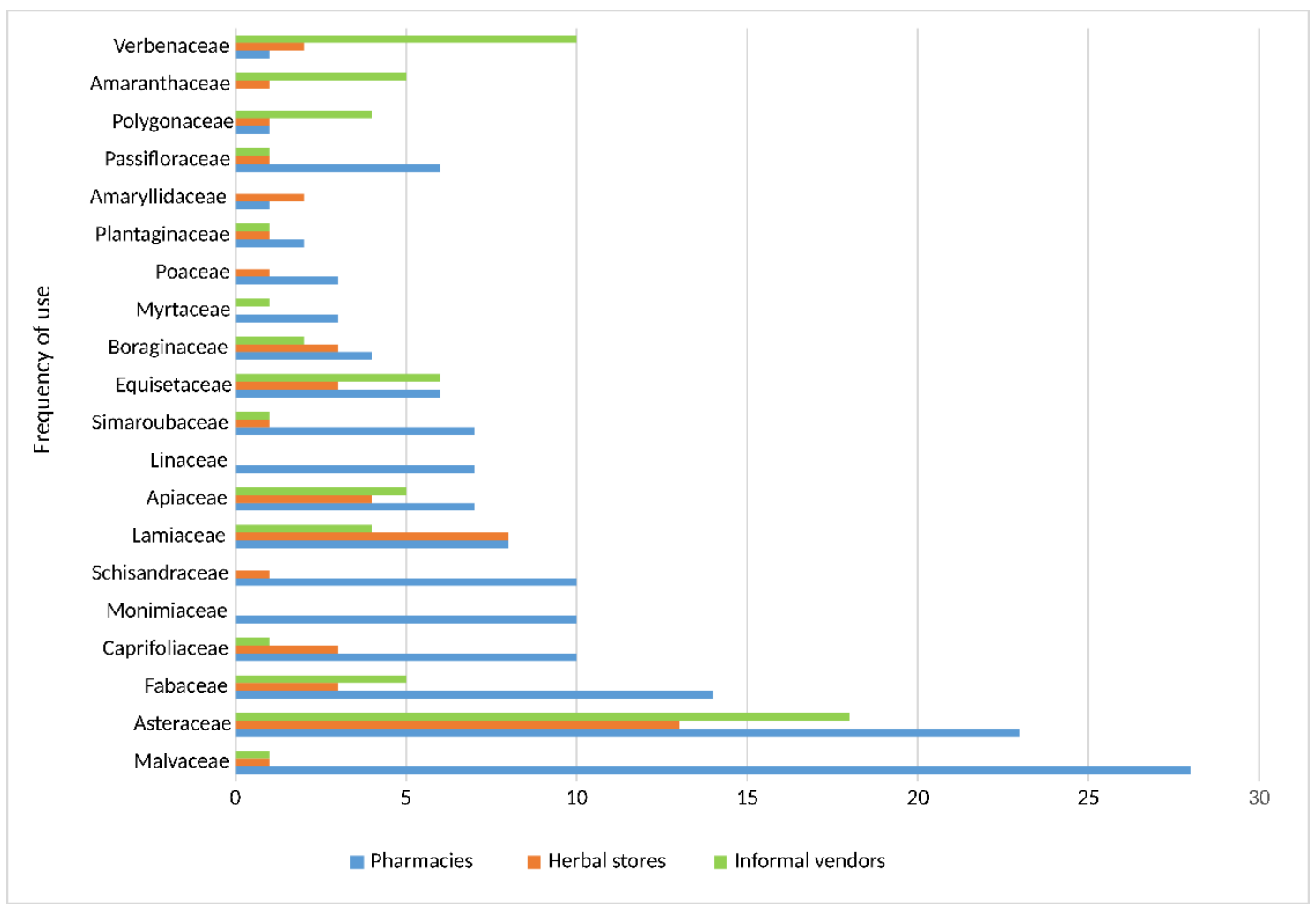

Figure 5. The most frequently found botanical families at the three supply sites. Only those with a frequency greater than $1 \%$ are included. $N=302$ (total species citations). The family names were ordered according to frequency of use.

ates conservation problems (Martínez 2005).

In accordance with our second hypothesis (c), the most common life forms recorded in total were herbs $(54 \%)$ and shrubs $(25 \%)$, followed by trees $(14 \%)$, climbing plants $(5 \%)$ and algae $(2 \%)$ (Chi-square test, $p<0.05)$. Numerous studies have highlighted herbs as the preferred life forms in the global pharmacopeia (Almeida et al. 2012; Cuassolo 2009; Hilgert et al. 2010; Pirondo et al. 2011; Pochettino et al. 1997; Pochettino et al. 2008; Santoro et al. 2015), a common pattern which was also found in this study when the three sites were analyzed individually (Table 3). The presence of strong bioactive compounds in the alien herb stratum is often highlighted; these plants, such as Taraxacum officinale, Borago officinalis and Matricaria chamomilla, are considered invasive and abundant herbs in some parts of Argentina, particularly in protected natural areas (Bertonatti 2010). Various studies also suggest that the more frequent use of herbs than other life forms is due to the ease with which they can be obtained and stored in the home for long periods of time (Faruque et al. 2018); it may also be related to their small-scale production and their recurring or spontaneous appearance in vegetable and home gardens (Ladio et al. 2013).

In accordance with global patterns and our third hypothesis, our results have shown that the most common medicinal use categories are gastrointestinal $(32 \%)$, genitourinary (13\%), Circulatory system problems (12\%), Respiratory system (9\%), Analgesicanti-inflammatory (9\%), Nervous system disorders $(6 \%)$ and Dermatological (4\%), Immune system and gynecological-obstetric (1\%) and Others (14\%) (Chisquare test, $p<0.05)$. Analysis of the medicinal use categories dealt with at each supply site revealed that gastrointestinal problems were the most prevalent (Table 3). These results coincide with other ethnobotanical studies that link this type of category with home remedies (Acosta et al. 2018; Cuassolo 2009; Hilgert et al. 2010; Moerman et al. 1999; Pochettino et al. 1997; Pochettino et al. 2008). Although official medical services are relatively well distributed in the city at the present time, plants collected in the countryside or obtained commercially are still more affordable for inhabitants. The high FU of genitourinary complaints is due to the inclusion of diuretics. Diuretics are substances that act within the kidney and promote the loss of fluid from the body, including compounds that must induce the loss of sodium. These properties are used to combat obesity, hypertension, high-fat diets and cardiovascular disorders (Wright et al. 2007). Problems of this 
type are often associated with urban society (Cuassolo 2009), and therefore in the cities this type of ailment is amongst the most common (Ladio and Acosta 2019).

One result worthy of note in this work is the absence of categories related to cultural affiliation, such as mal aire (bad air), or aicadura (related to contact with a dead body), among other complaints typical of the northwest Andean region of Argentina. Various authors point out that these belong to popular or regional medicine, whose illnesses and treatments are associated with local customs and beliefs (Idoyaga Molina 2001; Luján and Martínez 2017; Sato 2011). Although some authors may interpret the lack of records of these illnesses as loss or erosion of traditional knowledge, in fact it could be related to a methodological limitation of this study. Working with ethic re-categorization of illnesses meant it was impossible to investigate the most traditional categories in depth, thus effectively excluding them from this work (Ladio and Acosta 2019). However, this categorization type based on corporal system categories or common diseases is useful for assessment and comparison of variations across different regions or countries.

\section{Similarity of the plants sold at the dif- ferent supply sites}

It was found that there was low similarity of the species composition sold at the different types of supply site. The informal vendors and herbal stores shared the highest number of species (46\%), the main ones being southern cola de caballo (Equisetum giganteum L.), malva (Malva sylvestris L.), cedrón (Aloysia citrodora Palau), and pezuña de vaca (Bauhinia forficata Link). Informal vendors and pharmacies shared only $25 \%$ of the species sold, such as borage (Borago officinalis L.), pasionaria (Passiflora caerulea L.), and sen (Senna alexandrina Mill.). Furthermore, herbal stores and informal vendors shared the highest number of native species (75\%), while herbal stores and pharmacies shared a higher number of exotic species (57\%). The informal vendors and herbal stores shared a higher percentage of native species due to their long history of herbalism and are recognized by the population of Jujuy as valuable sites for plants and knowledge (Acosta et al. 2013). This aspect highlights the importance of having different types of supply site offering diverse options of medicinal plants. As found by several authors, herbal stores make a substantial biocultural contribution to the richness of local medicinal plants, and function as centers of knowledge of plants and herbal products (Arenas et al. 2011; Hurrell et al. 2011a; Pochettino et al. 2012). Nevertheless, the informal vendors sell fresh plants directly from the gatherers, thus offering better quality resources.

\section{Variation in the biogeographical origin of medicinal plants sold at each type of supply site}

In accordance with our fourth hypothesis, it was found that native plants were found less frequently in pharmacies (the least traditional supply sites) and herbal stores than in the informal supply sites (Tables 2 and $4 \mathrm{~A}$ ). In our study native plants were sold more often in stores that marketed only medicinal plants than in pharmacies, as found by Bach et al. (2014). The herbal stores and informal stalls sold mostly local products obtained from local gatherers, and they stocked the plants that local people asked for, or whatever was available. In contrast, the pharmacies bought packaged plants from national distributors. It is possible that exotic plants are more likely to be found in pharmacies due to information provided by the communication media, through television or online advertising, and the provision by laboratories and distributors of a certain range of plants prepared specifically for sale. To a lesser or greater extent, this information currently reaches both rural and urban buyers; therefore, the sales scenario and abundant circulation of information generated by the different media are extremely influential external factors when it comes to selling certain species (Pirondo et al. 2018).

It was also found that the importance of exotic in comparison with native species varied with species life form (Tables 2 and 4B). The results show that despite variations in the proportion of herbs used relative to trees and shrubs, the trees used are mainly native species, while the herbs are mostly exotic in origin, in accordance with our second hypothesis (c) (Tables 2 and 4B). Nevertheless, it has been suggested that the availability and accessibility of native medicinal plants in urban contexts continues to be an important factor, since it reflects the deep-seated traditions of a community (Acosta et al. 2018).

\section{CONCLUSION}

A general overview of urban medicinal systems is a good starting point for the design and implementation of multicultural health policies in cities, because all the plant richness used has a where and a why. The variety of medicinal species commercialized in the city of San Salvador de Jujuy shows us that the richness of exotic and native plants sold differed according to type of supply site: the less traditional sites, such as pharmacies, were more likely to offer exotic plants, while herbal stores and informal vendors offered more native plants. The informal stalls act as the most important points for the circulation and symbolic reservoir of native or wild species, mo- 
Table 4. Summary of the parameters of the GLM estimates. Wald is the chi-square that tests the null hypothesis, $\mathrm{df}=$ degrees of freedom, Sig = level of significance, $*$ significant results in the model at 0.05 . A. Between biogeographical origin and different supply sites. B. Between biogeographical origin and life form. Dependent variable: Origin; Model: (Interception) and Supply sites (A) /Life form (B). ${ }^{a}$ Defined as 0 because this parameter is redundant.

\begin{tabular}{cccccc}
\hline \hline A- & B & E.E. & Wald & df & Sig. \\
\hline \hline Intercept & 0.693 & 0.2449 & 8.008 & 1 & $0.005^{*}$ \\
Pharmacies & -2.492 & 0.3327 & 56.118 & 1 & $0.000^{*}$ \\
Herbal stores & -1.504 & 0.3636 & 17.109 & 1 & $0.000^{*}$ \\
Informal vendor & $0^{a}$ & - & - & - &.- \\
\hline \hline B- & $\mathrm{B}$ & E.E. & Wald & df & Sig. \\
\hline \hline Intercept & -1.168 & 0.1882 & 38.518 & 1 & $0.000^{*}$ \\
Herbs & -0.946 & 0.4422 & 4.580 & 1 & $0.032^{*}$ \\
Trees & 1.594 & 0.2951 & 29.186 & 1 & $0.000^{*}$ \\
Shrubs / creepers & $0^{a}$ & - & - & - & - \\
\hline \hline
\end{tabular}

tivating vendors to continue increasing the diversity of plants on offer from Andean regions. Furthermore, the most sold native medicinal plants are more versatile than the exotic species and are key to an effective response to different health needs in urban centers.

Thus, city dwellers, who for diverse reasons can no longer collect medicinal plants themselves, can have easy access to these plant resources. This phenomenon has notable consequences in terms of public health and demonstrates the biocultural role of these traditional sites. However, in terms of conservation of native Andean plants, future studies should be carried out to identify their commercialization circuits and evaluate the impact they generate on regional flora. Finally, having access to diverse medicinal plant supply strategies may contribute to inhabitants' socio ecological resilience, thus helping them face changes with autonomy and diversity.

\section{ACKNOWLEDGEMENT}

We are deeply grateful to Dr. Nilda Dora Vignale for collaborating in the identification of plant material and for sharing her knowledge and experience. We also thank Mg. Carlos H. A. Cabrera for drawing up the map of Jujuy province. This study was supported by the Consejo Nacional de Investigaciones Científicas y Técnicas (CONICET) of Argentina, the National University of Jujuy and ANPCyT (Agencia Nacional de Promoción Científica y Tecnológica -PICT-2018$-03395)$.

\section{DATA AVAILABILITY}

The data used to support the findings of this study are available from the corresponding author upon reasonable request.

\section{CONFLICT OF INTEREST}

The authors have no conflicts of interest to declare.

\section{CONTRIBUTION STATEMENT}

Conceived the idea: AL. Carried out the fieldwork: MA.

Carried out the data analysis: AL, MA. Wrote the first draft of the manuscript: AL, MA. Review and final writing of the manuscript: AL, MA, DAL, Supervision: AL.

\section{REFERENCES}

Abreu D, Santoro FR, Albuquerque UP, Ladio AH, Medeiros PM (2015) Medicinal plant knowledge in a context of cultural pluralism: a case study in Northeastern Brazil. Journal of Ethnopharmacology 175:124-130.

Acosta ME (2013) Etnobotánica urbana de las plantas medicinales nativas y exóticas comercializadas en la ciudad de San Salvador de Jujuy. Degree thesis, Universidad Nacional de Jujuy, Jujuy, Argentina. 
Acosta et al. 2021. Urban trading of medicinal plants in San Salvador de Jujuy (Argentina): How does species composition vary between different biocultural supply sites?

Ethnobio Conserv 10:34

Acosta ME, Vignale ND, Ladio AH (2013) Uso y comercialización de especies medicinales en la ciudad de SAN SALVADOR de JUJUY. Agraria 7:74-83.

Acosta ME, Ladio AH, Vignale ND (2018) Herbolaria migrante boliviana en un contexto periurbano del Noroeste Argentino. Boletin Latinoamericano y del Caribe de Plantas Medicinales y Aromaticas 17:217-237.

Agresti A (1996) An Introduction to Categorical Data Analysis. Wiley J (eds) Inc S. Nueva York. $1-290$.

Albuquerque UP, Cruz Da Cunha LVF, Lucena RFP, Alves RRN (2014) Methods and Techniques in Ethnobiology and Ethnoecology. Springer Protocols Handbooks.

Alencar NL, Araújo TAS, Amorim ELC, Albuquerque UP (2010) The inclusion and selection of medicinal plants in traditional pharmacopoeias - evidence in support of the diversification hypothesis. Economic Botany 64: 68-79.

Alencar NL, Santoro FR, Albuquerque UP (2014) What is the role of exotic medicinal plants in local medical systems? A study from the perspective of utilitarian redundancy. Brazilian Journal of Pharmacognosy 24:506-515.

Almeida CFCBR, Ramos MA, Silva RRV, Melo JG, Medeiros MFT, Araujo TAS, De Almeida ALS, De Amorim ELC, Alves RRN, Albuquerque UP (2012) Intracultural variation in the knowledge of medicinal plants in an urban-rural community in the Atlantic Forest from Northeastern Brazil. Evidence-based Complementary and Alternative Medicine 2012:1-15.

Arenas PM (2007) Suplementos dietéticos: estudio etnobotánico en zonas urbanas. Kurtziana 33:193-202.

Arenas PM, Cristina I, Puentes JP, Costantino FB, Hurrell JA, Pochettino ML (2011) Adaptógenos: Plantas medicinales tradicionales comercializadas como suplementos dietéticos en la conurbación Buenos Aires-La Plata (Argentina). Blonplandia 20:251-264.

Bach HG, Wagner ML, Ricco RA, Fortunato RH (2014) Sale of medicinal herbs in pharmacies and herbal stores in Hurlingham district, Buenos Aires, Argentina. Brazilian Journal of Pharmacognosy 24:258-264.

Balick M, Kronenberg F, Ososki A (2000) Medicinal plants used by Latino healers for women's health conditions in New York City. Economic Botany 54:344-357.
Balzarini M, Di Rienzo J, Tablada M, Gonzalez L, Bruno C, Córdoba M, Robledo W, Casanoves F (2011) Estadística y Biometría. Editorial Brujas. Argentina, pp. 1-404.

Barboza G, Cantero J, Núñez C, Pacciaroni A, Ariza Espinar L (2009) Medicinal plants: A general review and a phytochemical and ethnopharmacological screening of the native Argentine Flora. Kurtziana 34:7-365.

Bennett BC, Husby C (2008) Patterns of medicinal plant use: An examination of the Ecuadorian Shuar medicinal flora using contingency table and binomial analyses. Journal of etnhofarmacology 116:422-430.

Bertonatti C (2010) Del Escritorio al Campo: plantas exóticas, introducidas e invasoras de Argentina. Vida Silvestre 113.

Boelcke O (1992) Plantas vasculares de la República de la Argentina. Hemisferio Sur, 2da. edición, Buenos Aires, pp. 1-333.

Bussmann RW, Paniagua Zambrana NY, Moya Huanca LA, Hart R (2016) Changing markets Medicinal plants in the markets of La Paz and El Alto, Bolivia. Journal of Ethnopharmacology 193:76-95.

Cabrera AL (1976) Regiones Fitogeográficas Argentinas, In: Enciclopedia Argentina de Agricultura y Jardinería, $2^{\circ}$ ed., T II, Fasc. 1. Acme, Buenos Aires.

Cabrera AL (1978) Flora de la provincia de Jujuy. Colección Cientifica INTA 13:1- 726.

Cabrera AL (1983) Flora de la provincia de Jujuy. Colección Cientifica INTA 13:1-508.

Cabrera AL (1993) Flora de la provincia de Jujuy. Colección Científica INTA 13:1-560.

Caetano RA, Albuquerque UP, Medeiros PM (2020) What are the drivers of popularity and versatility of medicinal plants in local medical systems? Acta Botanica Brasilica 34:256-265.

Cañigueral S, Vila R, Wichtl M (1998) Plantas medicinales y drogas vegetales para infusión y tisana. OEMF international SRL, Italia.

Carrascal L (2015) Modelos Lineales Generalizados para SPSS. Museo Nacional de Ciencias Naturales. IMIDRA (Instituto Madrileño de Investigación y Desarrollo Rural, Agrario y Alimentario).

Castañeda R, Gutiérrez H, Carrillo É, Sotelo A (2017) Leguminosas (Fabaceae) silvestres de uso medicinal del distrito de Lircay, provincia de Angaraes (Huancavelica, Perú). Boletin 
Acosta et al. 2021. Urban trading of medicinal plants in San Salvador de Jujuy (Argentina): How does species composition vary between different biocultural supply sites?

Ethnobio Conserv 10:34

Latinoamericano y del Caribe de Plantas Medicinales y Aromaticas 16:136-149.

Ceuterick M, Vandebroek I, Pieroni A (2011) Resilience of Andean urban ethnobotanies: A comparison of medicinal plant use among Bolivian and Peruvian migrants in the United Kingdom and in their countries of origin. Journal of Ethnopharmacology 136:27-54.

Creswell JW (2007) Qualitative Inquiry and Research Design: Choosing Among Five Approaches. Sage publications.

Cuassolo F (2009) Estudio etnobotánico de las plantas medicinales nativas y exóticas comercializadas en la ciudad de Bariloche (Patagonia, Argentina). Degree thesis. Universidad Nacional del Comahue, Centro Regional Universitario Bariloche, Río Negro, Argentina.

Cuassolo F, Ladio AH, Ezcurra C (2010) Aspectos de la comercialización y control de calidad de las plantas medicinales más vendidas en una comunidad urbana del NO de la Patagonia Argentina. Boletin Latinoamericano y del Caribe de Plantas Medicinales y Aromaticas 9:166-176.

Davoudi S, Shaw K, Haider LJ, Quinlan AE, Peterson GD, Wilkinson C, Fünfgeld H, McEvoy D, Porter L (2012) Resilience: A Bridging Concept or a Dead End? "Reframing" Resilience: Challenges for Planning Theory and Practice Interacting Traps: Resilience Assessment of a Pasture Management System in Northern Afghanistan Urban Resilience: What Does it Mean in Planni. Planning Theory and Practice 13:299-333.

Faruque MO, Uddin SB, Barlow JW, Hu S, Dong S, Cai Q, Li X, Hu X (2018) Quantitative ethnobotany of medicinal plants used by indigenous communities in the Bandarban district of Bangladesh. Frontiers in Pharmacology 9:40.

Gama ADS, de Paula M, da Silva RRV, Ferreira WS, de Medeiros PM (2018) Exotic species as models to understand biocultural adaptation: Challenges to mainstream views of human-nature relations. PLoS ONE 13:1-18.

Guarrera PM (2005) Traditional phytotherapy in Central Italy (Marche, Abruzzo, and Latium). Fitoterapia 76:1-25.

Gurni AA, Wagner ML (2003) Farmacobotánica. Guía de Trabajos Prácticos. Facultad de farmacia y Bioquímica. Universidad de Buenos Aires, Argentina.

Hart G, Gaoue OG, de la Torre L, Navarrete H,
Muriel P, Macía MJ, Balslev H, León-Yánez S, Jørgensen P, Duffy DC (2017) Availability, diversification and versatility explain human selection of introduced plants in Ecuadorian traditional medicine. PloS One 12:e184369.

Hauman L (1984) Los géneros de fanerógamas de Argentina. Claves para su identificación. Boletín de la Sociedad Argentina de Botánica 23:1-384.

Heinrich M (1992) Economic botany of American Labiatae. In: Harley RM, Reynolds T (eds) Advances in Labiatae Science. Royal Botanic Gardens, Kew.

Hernández M, Arambarri A (2011) Recursos fitoterapéuticos y comportamiento poblacional en dos sectores de la ribera rioplatense de Berisso, Buenos Aires, Argentina. Bonplandia 20:137-148.

Hilgert NI, Higuera MDL, Kristensen MJ (2010) La medicina herbolaria en el contexto urbano. Estudio de caso en un barrio de la ciudad de Tandil, Argentina. Boletin Latinoamericano y del Caribe de Plantas Medicinales y Aromaticas 9:177-190.

Huamantupa I, Cuba M, Urrunaga R, Paz E, Ananya N, Callalli M, Pallqui N, Coasaca H (2011) Riqueza, uso y origen de plantas medicinales expendidas en los mercados de la ciudad del Cusco. Revista peruana de biología 18:283-291.

Hurrell JA (2014) Urban Ethnobotany in Argentina: Theoretical advances and methodological strategies. Ethnobiology and Conservation doi: ec2014-6-3.3-1-11.

Hurrell JA, Ulibarri EA, Arenas PM, Pochettino ML (2011a) Plantas de herboristería: plantas que se comercializan en herboristerías de la Ciudad de Buenos Aires. 1ra ed. L.O.L.A., Ciudad autónoma de Buenos Aires.

Hurrell J, Ulibarri E, Puentes J, Buet F, Arenas P, Pochettino M (2011b) Leguminosas medicinales y alimenticias utilizadas en la conurbación. Boletín Latinoamericano y del Caribe de Plantas Medicinales y Aromáticas 10:443-455.

Hurrell J, Arenas P, Cristina I (2015) El conocimiento botánico en zonas urbanas: potenciadores cognitivos comercializados en el área metropolitana de Buenos Aires, Argentina. Gaia 9:17-31.

Idoyaga Molina A (2001) Etiologías, síntomas y eficacia terapéutica. El proceso diagnóstico de la enfermedad en el noroeste argentino y cuyo. Mitológicas 16:9-43. 
Acosta et al. 2021. Urban trading of medicinal plants in San Salvador de Jujuy (Argentina): How does species composition vary between different biocultural supply sites?

Ethnobio Conserv 10:34

INDEC (2010) Población. Migración. Censos Nacionales. Buenos Aires. [htpp://www. Indec. gov.ar] Accessed June 12020.

ISE (2006) International Society of Ethnobiology. The ISE Code of Ethics.

Jackson BP, Snowdob DW (1990) Atlas of microscopy of medicinal plants, culinary herbs and spices. Belnaven Press, London.

Kachura A, Harris CS (2021) An Ethnobotanical Meta-Analysis of North American Medicinal Asteraceae. Canadian Science Botany doi: 10.1139/cjb-2021-0079.

Katinas L, Gutiérrez DG,Grossi MA, Crisci JV (2007) Panorama de la familia Asteraceae (= Compositae) en la Repíblica Argentina. Boletín de la Sociedad Argentina de Botánica 42:113-129.

Ladio AH, Molares S, Ochoa J, Cardoso B (2013) Etnobotánica aplicada en Patagonia: la comercialización de malezas de uso comestible y medicinal en una feria urbana de San Carlos de Bariloche (Río Negro, Argentina). Boletin Latinoamericano y del Caribe de Plantas Medicinales y Aromaticas 12:24-37.

Ladio AH, Acosta M (2019) Urban medicinal plant use: Do migrant and non-migrant populations have similar hybridisation processes? Journal of Ethnopharmacology 234:1-16.

Leitão F, Leitão SG, Fonseca-Kruel VS Da, Silva IM, Martins K (2014) Medicinal plants traded in the open-air markets in the State of Rio de Janeiro, Brazil: an overview on their botanical diversity and toxicological potential. Revista Brasileira de Farmacognosia 24:225-247.

Leonti M, Ramirez FR, Sticher O, Heinrich M, (2003) Medicinal flora of the Popoluca, México: A botanical systematical perspective. Economic Botany 57:218-230.

Luján M, Martínez G (2017) Dinámica del conocimiento etnobotánico en poblaciones urbanas y rurales de Córdoba (Argentina). Boletin Latinoamericano y del Caribe de Plantas Medicinales y Aromaticas 16:278-302.

Luján MC, Martínez GJ (2019) Etnobotánica médica urbana y periurbana de la ciudad de Córdoba (Argentina). Boletin Latinoamericano y del Caribe de Plantas Medicinales y Aromaticas 18:155-196.

Macía MJ, García E, Vidaurre PJ (2005) An ethnobotanical survey of medicinal plants commercialized in the markets of $\mathrm{La} \mathrm{Paz}$ and El Alto, Bolivia. Journal of ethnopharmacology
$97: 337-50$.

Martin G (2001) Etnobotánica. Manuales de Conservación. Serie "Plantas y gente". WWF- UNESCO. Edic. Nordan-Comunidad, Montevideo.

Martínez GJ (2005) Recolección y Comercialización de Plantas Medicinales en el Departamento Santa María, Provincia de Córdoba , Argentina. Acta Farmacéutica Bonaerense 24:575-584.

Medeiros PM (2013) Why is change feared? Exotic species in traditional pharmacopoeias. Ethnobiology and Conservation doi: 10.15451/ec20138-2.3-1-05.

Medeiros PM , Ferreira Júnior WS, Ramos MA, Silva TC da, Ladio AH, Albuquerque UP (2017) Why do people use exotic plants in their local medical systems? A systematic review based on Brazilian local communities. PLOS ONE 12:e0185358.

Moerman DE, Pemberton RW, Kiefer D, Berlin B (1999) A Comparative Analysis of five medicinal floras. Journal of Ethnobiology 19:49-67.

Molares S, Ladio A (2009) Ethnobotanical review of the Mapuche medicinal flora: Use patterns on a regional scale. Journal of Ethnopharmacology 122:251-260.

Molares S, Ladio AH (2012) The usefulness of edible and medicinal Fabaceae in argentine and Chilean Patagonia: Environmental availability and other sources of supply. Evidence-based Complementary and Alternative Medicine 2012:1-12.

Molares S, Arenas PM, Aguilar A (2012) Etnobotánica urbana de los productos vegetales adelgazantes comercializados en México DF. Boletin Latinoamericano y del Caribe de Plantas Medicinales y Aromaticas 11:400-412.

Nascimento ALB, Medeiros PM, Albuquerque UP (2018) Factors in hybridization of local medical systems: Simultaneous use of medicinal plants and modern medicine in Northeast Brazil. PLoS ONE 13:1-14.

OIM (2015) Informes sobre las Migraciones en el Mundo 2015. Los migrantes y las ciudades: Nuevas colaboraciones para gestionar la movilidad.

Pirondo A, Coulleri JP, Keller HA, Ferrucci MS (2011) Influencia de factores externos sobre la comercialización de plantas medicinales en un medio urbano: El caso de vendedores criollos e indígenas en Corrientes, Argentina. Boletin Latinoamericano y del Caribe de Plantas Medicinales y Aromaticas 10:553-569. 
Acosta et al. 2021. Urban trading of medicinal plants in San Salvador de Jujuy (Argentina): How does species composition vary between different biocultural supply sites?

Ethnobio Conserv 10:34

Pirondo A, Michlig A, Martín SG, Keller HA (2018) Constitution and characteristics of the Ibereño herbolarium: A case study within Iberá wetlands (Corrientes, Argentina). Boletin Latinoamericano y del Caribe de Plantas Medicinales y Aromaticas 17:394-413.

Pochettino ML, Martínez MR, Itten B, Zucaro M (1997) El uso de plantas medicinales en la atención primaria de la salud: estudio etnobotánico en una población urbana (La Plata, Buenos Aires, Argentina). Parodiana 10:141-152.

Pochettino ML, Arenas P, Sánchez D, Correa R (2008) Conocimiento botánico tradicional, circulación comercial y consumo de plantas medicinales en un área urbana de Argentina. Boletin Latinoamericano y del Caribe de Plantas Medicinales y Aromaticas 7:141-148.

Pochettino ML, Puentes JP, Buet Costantino F, Arenas PM, Ulibarri EA, Hurrell JA (2012) Functional foods and nutraceuticals in a market of Bolivian immigrants in Buenos Aires (Argentina). Evidence-based Complementary and Alternative Medicine 2012:1-14.

Porqueddu T (2017) Herbal medicines for diabetes control among Indian and Pakistani migrants with diabetes. Anthropolgy Medica 24:17-31.

Real R, Vargas JM (1996) The probabilistic basis of Jaccard's index of similarity. Systematic Biology 45:380-385.

Richeri M (2009) El uso de las plantas medicinales en la comunidad boliviana de Puerto Madryn. Degree thesis, Unidad Jardín Botánico de la Patagonia Extraandina, Chubut, Argentina.

Richeri M, Beeskow M, Ladio A (2012) Las plantas y la salud en una comunidad boliviana, Madryn (Argentina). In: Tradiciones y Transformaciones en Etnobotánica. ICEB, pp. 297-302.

Richeri M, Ladio AH, Beeskow AM (2013) Conocimiento tradicional y autosuficiencia: La herbolaria rural en la meseta central del chubut (Argentina). Boletin Latinoamericano y del Caribe de Plantas Medicinales y Aromaticas 12:44-58.

Rossi-Santos B, de Oliveira Jacintho J, Milliken W, Messias MCTB (2018) The Role of Exotic Species in Traditional Pharmacopeias of the Cerrado: a Case Study in Southeast Brazil. Economic Botany 72:38-55.

Saslis-Lagoudakis CH, Savolainen V, Williamson EM, Forest F, Wagstaff SJ, Baral SR, Watson MF,
Pendry CA, Hawkins JA (2012) Phylogenies reveal predictive power of traditional,medicinein bioprospecting. Proceedings of the National Academy of Sciences of the United States of America 109:15835-15840.

Santoro FR, Ferreira Junior WS, De Araujo TAS, Ladio AH, Albuquerque UP (2015) Does plant species richness guarantee the resilience of local medical systems? A perspective from utilitarian redundancy. PLoS ONE 10:1-18.

Santoro FR, Nascimento ALB, Soldati GT, Ferreira Júnior WS, Albuquerque UP (2018) Evolutionary ethnobiology and cultural evolution: Opportunities for research and dialog. Journal of Ethnobiology and Ethnomedicine 14:1-14.

Sato MS (2011) El uso de las plantas medicinales en una localidad del noroeste argentino (Perico, Dpto. El Carmen, Jujuy). Degree thesis, Universidad Nacional de Córdoba.

Smith-Hall C, Larsen HO, Pouliot M (2012) People, plants and health: a conceptual framework for assessing changes in medicinal plant consumption. Journal of Ethnobiology and Ethnomedicine $8: 43$.

Stepp JR (2004) The role of weeds as sources of pharmaceuticals. Journal of Ethnopharmacology 92:163-166.

Stepp JR, Moerman DE (2001) The importance of weeds in ethnopharmacology. Journal of Ethnopharmacology 75:19-23.

Souza ENF, Williamson EM, Hawkins JA (2018) Which plants used in ethnomedicine are characterized? Phylogenetic patterns in traditional use related to research effort. Frontiers in Plant Science 9:1-12.

Tardío J, Pardo de Santayana M (2008) Cultural importance indices: a comparative analysis based on the useful wild plants of southern Cantabria (Northern Spain). Economic Botany 62:24-39.

Tareau MA, Palisse M, Odonne G (2017) As vivid as a weed... Medicinal and cosmetic plant uses amongst the urban youth in French Guiana. Journal of Ethnopharmacology 203:200-213.

Tinitana F, Rios M, Romero-Benavides JC, De La Cruz Rot M, Pardo-De-Santayana M (2016) Medicinal plants sold at traditional markets in southern Ecuador. Journal of Ethnobiology and Ethnomedicine 12:1-18.

Vandebroek I, Calewaert JB, De Jonckheere S, Sanca S, Semo L, Van Damme P, Van Puyvelde L, De Kimpe N (2004) Use of Medicinal Plants and pharma- 
ceuticals by indigenous communities in the Bolivian Andes and Amazon. Bulletin of The World Health Organization 82:243-250.

Vignale (2001) Los estudios Etnobotánicos en el NOA. Las plantas medicinales. Journal of Chemical Information and Modeling 53:1689-1699.

Vignale ND (2002) Relevamiento y análisis exomorfológico y micrográfico de plantas medicinales de la puna y prepuna jujeñas, con especial referencia a la Reserva de Biósfera Laguna de Pozuelos, Jujuy, Argentina. Ph D Thesis. Facultad de Farmacia y Bioquímica, Universidad de Buenos Aires.

Vidaurre PJ (2006) Plantas medicinales en los Andes de Bolivia. Botánica Económica de los Andes Centrales 268-284.

Vignale ND, Gurni AA (2009) Parámetros micrográficos para identificar doce especies medicinales andinas de Asteraceae de la provincia de Jujuy, Argentina. In: Vignale ND, Pochettino ML (eds) Avances sobre plantas medicinales andinas, pp. 129-204.

Wright CI, Van-Buren L, Kroner CI, Koning MMG (2007) Herbal Medicines as Diuretics: A Review of the Scientific Evidence. Journal of ethnopharmacology 114:1-31.

Zhou W, Fisher B, Pickett ST (2019) Cities are hungry for actionable ecological knowledge. Frontiers in Ecology and the Environment 17:135-135.

Zuloaga FO, Morrone O (1999) Catálogo de las plantas vasculares de la República Argentina. II. Dicotyledoneae. Monographs in Systematic Botany from Missouri Botanical Garden 74:1-1269.

Zuloaga FO, Morrone O, Rodríguez D (1999) Análisis de la Biodiversidad en plantas vasculares de la Argentina. Kurtziana 27:17-167.

Zuloaga FO, Morrone O, Belgrano M (2008) Catálogo de Plantas Vasculares del Cono Sur (Argentina, Sur de Brasil, Chile, Paraguay y Uruguay) Pteridophyta, Gimnospermae Monocotyledoneae. Monographs in Systematic Botany from Missouri Botanical Garden 107:1-3348.

Received: 28 June 2021

Accepted: 21 September 2021

Published: 28 October 2021

Editor: Ulysses Albuquerque 
Add File 1. Most commercialized medicinal species in S. S. de Jujuy, in descending order of frequency of citation $(\mathrm{FC})$. Origin: $\mathrm{N}=$ native, $\mathrm{E}=\mathrm{exotic}$; Parts used: $\mathrm{L}=$ leaves, $\mathrm{SP}=$ stems and petioles, $\mathrm{FL}=$ flowers, $\mathrm{Fr}=$ fruits, $\mathrm{S}=$ seeds, $\mathrm{BT}=$ bark, trunk, wood, $\mathrm{R}=$ roots, rhizomes, $\mathrm{B}=$ bulbs; $\mathrm{WP}=$ whole plant; $\mathrm{AP}=$ aerial parts; Therapeutic uses: $\mathrm{GI}=$ gastrointestinal, GU = genitourinary, AA $=$ analgesic-anti-inflammatory RS $=$ respiratory system disorders, $\mathrm{DE}=$ dermatological, $\mathrm{GO}=$ gynecological-obstetric, $\mathrm{C}=$ circulatory system problems, NS $=$ nervous system disorders, $\mathrm{F}=$ febrifuge, OT $=$ other ; Versatility $=$ number of therapeutic uses.

\begin{tabular}{|c|c|c|c|c|c|c|c|c|c|}
\hline Scientific name & $\begin{array}{l}\text { Local } \\
\text { name }\end{array}$ & Family & Life form & $\begin{array}{l}\text { Used } \\
\text { parts }\end{array}$ & Origen & $\begin{array}{c}\text { Therapeutic } \\
\text { uses }\end{array}$ & Versatility & FC & $\begin{array}{l}\text { Preparation } \\
\text { form }\end{array}$ \\
\hline Matricaria chamomilla L. & manzanilla & Asteraceae & herbs & FL & $\mathrm{E}$ & $\begin{array}{l}\text { GI, DE, GO, } \\
\text { NS, AA, OT }\end{array}$ & 6 & 21 & $\begin{array}{l}\text { Infusion, } \\
\text { washings, } \\
\text { ointment, Juice }\end{array}$ \\
\hline Tilia cordata Mill. & tilo & Malvaceae & tree & FL & $\mathrm{E}$ & NS & 1 & 17 & Infusion \\
\hline Senna alexandrina Mill. & sen & Fabaceae & shrub & $\mathrm{L}$ & $\mathrm{E}$ & GI & 1 & 16 & Infusion \\
\hline Equisetum giganteum L. & cola de caballo & Equisetaceae & herbs & $\mathrm{AP}$ & $\mathrm{N}$ & $\begin{array}{l}\text { GI, GU, } \\
\mathrm{AA}, \mathrm{OT}\end{array}$ & 4 & 15 & $\begin{array}{l}\text { Infusion, } \\
\text { Juice }\end{array}$ \\
\hline Valeriana officinalis L. & valeriana & Caprifoliaceae & herbs & $\mathrm{R}$ & $\mathrm{E}$ & NS & 1 & 14 & Infusion \\
\hline Malva sylvestris $\mathrm{L}$. & malva & Malvaceae & herbs & $\mathrm{L}, \mathrm{SP}$ & $\mathrm{E}$ & GI, GU, AA & 3 & 13 & $\begin{array}{l}\text { Infusion, } \\
\text { washings, } \\
\text { ointment }\end{array}$ \\
\hline Illicium verum Hook.f. & anís estrellado & Schisandraceae & tree & FL, Fr, S & $\mathrm{E}$ & GI & 1 & 11 & Infusion \\
\hline Peumus boldus Molina & boldo & Monimiaceae & tree & $\mathrm{L}$ & $\mathrm{E}$ & GI, & 1 & 10 & Infusion \\
\hline Picrasma excelsa (Sw.) Planch. & cuassia amargo & Simaroubaceae & tree & BT & $\mathrm{E}$ & GI, OT & 2 & 9 & $\begin{array}{l}\text { Infusion } \\
\text { Decoction }\end{array}$ \\
\hline Passiflora caerulea L. & $\begin{array}{l}\text { pasiflora / } \\
\text { pasionaria }\end{array}$ & Passifloraceae & creeper & $\mathrm{AP}$ & $\mathrm{N}$ & NS & 1 & 8 & $\begin{array}{l}\text { Infusion } \\
\text { Decoction }\end{array}$ \\
\hline Borago officinalis L. & borraja & Boraginaceae & herbs & $\mathrm{L}, \mathrm{SP}$ & $\mathrm{E}$ & GI, RS & 2 & 8 & Infusion \\
\hline Linum usitatissimum $\mathrm{L}$. & lino & Linaceae & herbs & $\mathrm{S}$ & $\mathrm{E}$ & GI, OT & 2 & 7 & Infusion \\
\hline Fucus sp. & fucus & Fucaceae & algae & talo & $\mathrm{E}$ & GI, GU, GO & 3 & 6 & $\begin{array}{l}\text { Infusion, } \\
\text { Decoction }\end{array}$ \\
\hline Indeterminada & zarzaparrilla & Polygonaceae & creeper & $\mathrm{R}$ & $\mathrm{N}$ & GU, C, AA & 3 & 6 & $\begin{array}{l}\text { Infusion, } \\
\text { Decoction }\end{array}$ \\
\hline Vachellia sp. & tusca & Fabaceae & tree & $\mathrm{BT}$ & $\mathrm{N}$ & $\begin{array}{l}\text { GI, GU, } \\
\text { DE, AA }\end{array}$ & 4 & 5 & $\begin{array}{l}\text { Infusion, } \\
\text { ointment }\end{array}$ \\
\hline Aloysia citriodora Palau & cedrón & Verbenaceae & shrub & $\mathrm{L}, \mathrm{SP}$ & $\mathrm{N}$ & $\begin{array}{l}\text { GI, C, } \\
\text { NS, OT }\end{array}$ & 4 & 5 & $\begin{array}{l}\text { Infusion, } \\
\text { Juice }\end{array}$ \\
\hline $\begin{array}{l}\text { Azorella ulicina } \\
\text { (Gillies \& Hook.) G.M. Plunkett \& } \\
\text { A.N. Nicolas }\end{array}$ & $\begin{array}{l}\text { espina amarilla / } \\
\text { chuquicanguia }\end{array}$ & Apiaceae & herbs & WP & $\mathrm{N}$ & $\mathrm{C}$ & 1 & 5 & Infusion \\
\hline cf. Nepeta cataria L. & melisa / toronjil & Lamiaceae & herbs & $\mathrm{L}, \mathrm{SP}$ & $\mathrm{E}$ & NS, OT & 2 & 5 & Infusion \\
\hline
\end{tabular}


Pimpinella anisum L.

Plantago major L.

Eucalyptus sp.

Baccharis articulata (Lam.) Pers.

Baccharis sp.

Clinopodium gilliesii

(Benth.) Kuntze.

Stevia rebaudiana

(Bertoni) Bertoni

Salvia hispanica L.

\section{Aristolochia sp.}

Cecropia pachystachya Trécul

Ligaria cuneifolia

(Ruiz \& Pav.) Tiegh.

Senecio nutans Sch.Bip.

Xenophyllum poposum

(Phil.) V.A.Funk

cf. Hyssopus officinalis L.

Vaccinium corymbosum $\mathrm{L}$.

Dysphania mandonni (S. Watson)

Mosyakin \& Clemants

Smallanthus sonchifolius

(Poepp.) H.Rob.

Zea mays L.

Centella asiatica (L.) Urb.

Frangula purshiana Cooper.

Aloysia salsoloides (Griseb.)

Lu-Irving \& O'Leary

Aloysia polystachya

(Griseb.) Moldenke

Azorella compacta Phil.

Lampayo castellani Moldenke

Dysphania ambrosioides

(L.) Mosyakin \& Clemants

Lepidium didymum $\mathrm{L}$.

Artemisia absinthium L.

\begin{tabular}{|c|c|c|c|c|c|}
\hline anís & Apiaceae & herbs & $\mathrm{S}$ & $\mathrm{E}$ & GI, AA \\
\hline llantén & Plantaginaceae & herbs & $\mathrm{L}, \mathrm{SP}$ & $\mathrm{E}$ & GI, GU \\
\hline eucalipto & Myrtaceae & tree & $\mathrm{L}$ & $\mathrm{E}$ & $\mathrm{RS}$ \\
\hline carqueja & Asteraceae & shrub & $\mathrm{L}, \mathrm{SP}$ & $\mathrm{N}$ & GI, GU \\
\hline carqueja & Asteraceae & shrub & $\mathrm{L}, \mathrm{SP}$ & $\mathrm{N}$ & GI, GU \\
\hline muña muña & Lamiaceae & shrub & $\mathrm{L}$ & $\mathrm{N}$ & GI, NS,OT \\
\hline estevia & Asteraceae & herbs & $\mathrm{L}$ & $\mathrm{N}$ & GI, C \\
\hline chía & Lamiaceae & herbs & $\mathrm{S}$ & $\mathrm{E}$ & $\mathrm{GU}, \mathrm{C}, \mathrm{OT}$ \\
\hline mil hombres & Aristolochiaceae & creeper & $\mathrm{L}, \mathrm{BT}$ & $\mathrm{N}$ & GI, GU, C \\
\hline ambay & Urticaceae & tree & $\mathrm{L}$ & $\mathrm{E}$ & $\mathrm{RS}$ \\
\hline muérdago & Loranthaceae & shrub & $\mathrm{L}$ & $\mathrm{N}$ & $\mathrm{C}$ \\
\hline chachacoma & Asteraceae & shrub & $\mathrm{L}$ & $\mathrm{N}$ & $\begin{array}{l}\text { GI, GU, } \\
\text { RS, C }\end{array}$ \\
\hline pupusa & Asteraceae & shrub & $\mathrm{AP}$ & $\mathrm{N}$ & $\mathrm{RS}, \mathrm{C}, \mathrm{OT}$ \\
\hline hisopo & Lamiaceae & shrub & $\mathrm{L}, \mathrm{SP}$ & $\mathrm{E}$ & GI, RS \\
\hline arándano & Ericaceae & shrub & Fr & $\mathrm{E}$ & GU \\
\hline arca & Amaranthaceae & herbs & $\mathrm{L}, \mathrm{FL}$ & $\mathrm{N}$ & GI, OT \\
\hline yacón & Asteraceae & herbs & $\mathrm{L}, \mathrm{R}$ & $\mathrm{E}$ & $\mathrm{C}$ \\
\hline estigma de maíz & Poaceae & herbs & $\mathrm{FL}$ & $\mathrm{N}$ & $\mathrm{GU}$ \\
\hline centella asiática & Apiaceae & herbs & $\mathrm{L}$ & $\mathrm{E}$ & $\mathrm{C}$ \\
\hline cáscara sagrada & Rhamnaceae & tree & BT & $\mathrm{E}$ & GI \\
\hline rica rica & Verbenaceae & shrub & $\mathrm{L}$ & $\mathrm{N}$ & GI, OT \\
\hline burro & Verbenaceae & shrub & $\mathrm{L}$ & $\mathrm{N}$ & GI \\
\hline yareta & Apiaceae & shrub & $\mathrm{WP}$ & $\mathrm{N}$ & $\mathrm{C}$ \\
\hline lampaya & Verbenaceae & shrub & $\mathrm{L}$ & $\mathrm{N}$ & GI \\
\hline paico & Amaranthaceae & herbs & $\mathrm{L}, \mathrm{SP}$ & $\mathrm{N}$ & GI \\
\hline quimpe & Brassicaceae & herbs & $\mathrm{WP}$ & $\mathrm{N}$ & SI \\
\hline ajenjo & Asteraceae & herbs & $\mathrm{L}$ & $\mathrm{E}$ & GI \\
\hline
\end{tabular}

Edible

Infusion,

poultice

Infusion,

vapours

Infusion,

Maceration

Infusion,

Maceration

4 Infusion

Infusion

Edible

Infusion,

Decoction

Infusion

Infusion

Infusion

Infusion

Infusion

Edible y

Syrup

Infusion

Infusion

Infusion

Infusion

Infusion

Infusion

Infusion,

Maceration

Infusion

Infusion

Infusion,

Decoction

Infusion,

Maceration

Infusion 
Artemisia vulgaris L.

Centaurea benedicta (L.) L.

Cynara cardunculus $\mathrm{L}$.

Malva parviflora L.

Mentha sp.

Sesamum indicum L.

Spirulina sp.

Uncaria tomentosa

(Willd. ex Schult.) DC.

Bauhinia forficata Link

Jodina rhombifolia

(Hook. \& Arn.) Reissek

Cinnamomum verum J.Presl

Ginkgo biloba L.

Krameria lappacea (Dombey)

Burdet \& B.B. Simpson

Lophophytum leandrii Eichler

Maytenus officinalis Mabb.

Phyllanthus sellowianus

(Klotzsch) Müll.Arg.

Lippia sp.

Rosa sp.

Rosmarinus officinalis L.

Achyrocline cf. satureioides

(Lam.) DC.

Amaranthus muricatus

(Gillies ex Moq.) Hieron.

Lepidium meyenii Walp.

Airampoa ayrampo

(Azara) Doweld

Xanthium spinosum L.

Allium sativum $\mathrm{L}$.

Allium cepa $\mathrm{L}$.

Aloe sp.

Apium sp.

Croton sp.

Heliotropium curassavicum $\mathrm{L}$.

Ocimum basilicum L.

Panicum miliaceum $\mathrm{L}$.

Papaver somniferum $\mathrm{L}$.

Piper aduncum $\mathrm{L}$.

\begin{tabular}{|c|c|c|c|c|c|}
\hline altamisa & Asteraceae & herbs & $\mathrm{L}, \mathrm{SP}$ & $\mathrm{E}$ & \\
\hline cardo santo & Asteraceae & herbs & $\mathrm{L}, \mathrm{FL}$ & $\mathrm{E}$ & GI, GU \\
\hline alcachofa & Asteraceae & herbs & $\mathrm{L}$ & $\mathrm{E}$ & GI \\
\hline malva & Malvaceae & herbs & $\mathrm{L}, \mathrm{SP}$ & $\mathrm{E}$ & $\begin{array}{l}\text { GI,DE, GO, } \\
\text { C, AA }\end{array}$ \\
\hline menta & Lamiaceae & herbs & $\mathrm{L}$ & $\mathrm{E}$ & GI, OT \\
\hline sésamo & Pedaliaceae & herbs & $\mathrm{S}$ & $\mathrm{E}$ & OT \\
\hline espirulina & Cianophyceae & algae & talo & $\mathrm{E}$ & OT \\
\hline uña de gato & Rubiaceae & creeper & BT & $\mathrm{E}$ & $\mathrm{RS}, \mathrm{AA}$ \\
\hline uña de vaca & Fabaceae & tree & $\mathrm{L}$ & $\mathrm{N}$ & GI \\
\hline sombra de toro & Santalaceae & tree & $\mathrm{L}$ & $\mathrm{N}$ & GI \\
\hline canela & Lauraceae & tree & $\mathrm{C}$ & $\mathrm{E}$ & GI \\
\hline gingo biloba & Ginkgoaceae & tree & $\mathrm{L}$ & $\mathrm{E}$ & OT \\
\hline chipi chape & Krameriaceae & shrub & SP & $\mathrm{N}$ & AA \\
\hline rompepiedra & Balanophoraceae & shrub & BT & $\mathrm{N}$ & GI, GU \\
\hline congorosa & Celastraceae & shrub & $\mathrm{L}, \mathrm{FL}$ & $\mathrm{N}$ & GI \\
\hline sarandí & Phyllanthaceae & shrub & $\mathrm{BT}$ & $\mathrm{N}$ & $\mathrm{C}$ \\
\hline poléo & Verbenaceae & shrub & $\mathrm{L}$ & $\mathrm{E}$ & GI \\
\hline pétalos de rosa & Rosaceae & shrub & FL & $\mathrm{E}$ & GI, OT \\
\hline romero & Lamiaceae & shrub & $\mathrm{L}$ & $\mathrm{E}$ & GI \\
\hline vira vira & Asteraceae & herbs & $\mathrm{L}$ & $\mathrm{N}$ & $\mathrm{RS}$ \\
\hline yerba meona & Amaranthaceae & herbs & $\mathrm{L}$ & $\mathrm{N}$ & GU \\
\hline maca & Brassicaceae & herbs & $\mathrm{R}$ & $\mathrm{N}$ & OT \\
\hline airampo & Cactaceae & herbs & $\mathrm{S}$ & $\mathrm{N}$ & $\mathrm{DE}$ \\
\hline cepa caballo & Asteraceae & herbs & $\mathrm{L}, \mathrm{SP}$ & $\mathrm{N}$ & GI \\
\hline ajo & Amaryllidaceae & herbs & B & $\mathrm{E}$ & $\mathrm{C}$ \\
\hline cebolla morada & Amaryllidaceae & herbs & B & $\mathrm{E}$ & GI,RS \\
\hline aloe vera & Amaryllidaceae & herbs & $\mathrm{L}$ & $\mathrm{E}$ & $\mathrm{DE}$ \\
\hline apio del norte & Apiaceae & herbs & $\mathrm{L}, \mathrm{SP}$ & $\mathrm{E}$ & GU \\
\hline pulmonaria & Euphorbiaceae & herbs & $\mathrm{L}$ & $\mathrm{E}$ & $\mathrm{RS}$ \\
\hline $\begin{array}{l}\text { doble grama / } \\
\text { heliotropo }\end{array}$ & Boraginaceae & herbs & $\mathrm{L}$ & $\mathrm{E}$ & OT \\
\hline albahaca & Lamiaceae & herbs & $\mathrm{L}$ & $\mathrm{E}$ & GI,NS \\
\hline mijo & Poaceae & herbs & $\mathrm{S}$ & $\mathrm{E}$ & OT \\
\hline amapola & Papaveraceae & herbs & Fr & $\mathrm{E}$ & RS, NS \\
\hline matico & Piperaceae & herbs & $\mathrm{L}$ & $\mathrm{E}$ & RS, OT \\
\hline
\end{tabular}

Decoction

Infusion

Infusion

Infusion,

washings,

ointments

Infusion

Edible

Edible

Decoction

Infusion

Infusion

Infusion

Infusion

Infusion

Decoction

Infusion

Decoction

Infusion

Infusion

Infusion

Infusion

Infusion

Infusion

Infusion

Infusion

Edible

Decoction

Edible

Infusion

Infusion

Infusion

Edible

Infusion

Infusion 
cf. Silybum marianum

(L.) Gaertn.

Taraxacum officinale (L.)

Weber ex F.H.Wigg.

Urtica urens $\mathrm{L}$.

Verbena sp.

Zingiber officinale Roscoe cardo mariano

diente de león

ortiga

verbena jengibre

$\begin{array}{lllll}\text { Asteraceae } & \text { herbs } & \text { L, SP } & \text { E } & \text { GI } \\ \text { Asteraceae } & \text { herbs } & \text { L, BT } & \text { E } & \text { GI } \\ \text { Urticaceae } & \text { herbs } & \text { L } & \text { E } & \text { GU, C } \\ \text { Verbenaceae } & \text { herbs } & \text { L } & \text { E } & \text { AA } \\ \text { Zingiberaceae } & \text { herbs } & \text { BT } & \text { E } & \text { GI }\end{array}$

$\begin{array}{lll}1 & 1 & \text { Infusion } \\ 1 & 1 & \begin{array}{l}\text { Infusion, } \\ \text { Decoction }\end{array} \\ 2 & 1 & \text { Infusion } \\ 1 & 1 & \text { Decoction } \\ 1 & 1 & \text { Decoction }\end{array}$

